\title{
Neurog1 and Neurog2 Control Two Waves of Neuronal Differentiation in the Piriform Cortex
}

\author{
Rajiv Dixit, ${ }^{1 \star}$ Grey Wilkinson, ${ }^{1 \star}$ Gonzalo I. Cancino, ${ }^{3}$ Tarek Shaker, ${ }^{1}$ Lata Adnani, ${ }^{1}$ Saiqun Li, ${ }^{1}$ Daniel Dennis, ${ }^{1}$ \\ Deborah Kurrasch, ${ }^{1}$ Jennifer A. Chan, ${ }^{2}$ Eric C. Olson, ${ }^{4}$ David R. Kaplan, ${ }^{3,5}$ Céline Zimmer, ${ }^{6}$ and Carol Schuurmans ${ }^{1}$ \\ ${ }^{1}$ Departments of Biochemistry and Molecular Biology and Medical Genetics, Hotchkiss Brain Institute and Alberta Children's Hospital Research Institute, \\ 2Department of Pathology and Laboratory Medicine, Southern Alberta Cancer Research Institute, University of Calgary, Alberta T2N 4N1, Canada, \\ ${ }^{3}$ Programs in Cell Biology, and Developmental and Stem Cell Biology, Hospital for Sick Children, Toronto M5G 1L7, Canada, ${ }^{4}$ Department of Neuroscience \\ and Physiology, SUNY Upstate Medical University, Syracuse, New York 13210, 5 Institute of Medical Science and Department of Molecular Genetics,

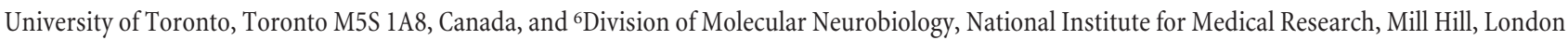 \\ NW7 1AA, United Kingdom
}

The three-layered piriform cortex, an integral part of the olfactory system, processes odor information relayed by olfactory bulb mitral cells. Specifically, mitral cell axons form the lateral olfactory tract (LOT) by targeting lateral olfactory tract (lot) guidepost cells in the piriform cortex. While lot cells and other piriform cortical neurons share a pallial origin, the factors that specify their precise phenotypes are poorly understood. Here we show that in mouse, the proneural genes Neurog1 and Neurog2 are coexpressed in the ventral pallium, a progenitor pool that first gives rise to Cajal-Retzius (CR) cells, which populate layer I of all cortical domains, and later to layer II/III neurons of the piriform cortex. Using loss-of-function and gain-of-function approaches, we find that Neurog1 has a unique early role in reducing CR cell neurogenesis by tempering Neurog2's proneural activity. In addition, Neurog1 and Neurog2 have redundant functions in the ventral pallium, acting in two phases to first specify a CR cell fate and later to specify layer II/III piriform cortex neuronal identities. In the early phase, Neurog1 and Neurog2 are also required for lot cell differentiation, which we reveal are a subset of CR neurons, the loss of which prevents mitral cell axon innervation and LOT formation. Consequently, mutation of Trp73, a CR-specific cortical gene, results in lot cell and LOT axon displacement. Neurog1 and Neurog2 thus have unique and redundant functions in the piriform cortex, controlling the timing of differentiation of early-born CR/lot cells and specifying the identities of later-born layer II/III neurons.

Key words: Cajal-Retzius neurons; lateral olfactory tract guidepost cells; Neurog1 and Neurog2; piriform cortex; proneural genes; ventral pallium

\section{Introduction}

The cerebral cortex, which includes the archicortex, neocortex, and piriform cortex, is derived from the dorsal telencephalon, or pallium. Based on gene expression, the pallium is subdivided into medial, dorsal, lateral, and ventral domains, each giving rise to distinct cortical territories (Puelles et al., 2000; Yun et al., 2001). Cajal-Retzius (CR) cells are an early-born cortical lineage, differentiating between embryonic day (E) 10.5 and E12.5 in mouse

Received Feb. 8, 2013; revised Nov. 17, 2013; accepted Nov. 20, 2013.

Author contributions: R.D., D.K., C.Z., and C.S. designed research; R.D., G.W., G.I.C., T.S., L.A., S.L., D.D., and C.Z. performed research; G.I.C., D.K., J.C., E.C.O., and D.R.K. contributed unpublished reagents/analytic tools; R.D., G.W., C.Z., and C.S. analyzed data; R.D., C.Z., and C.S. wrote the paper.

This work was supported by a Canadian Institutes of Health Research (CIHR; MOP-44094) Operating Grant to C.S., C.S. is an Alberta Innovates Health Solutions Senior Scholar. R.D. was supported by a CIHR Canada Hope Scholarship and G.W. and S.L. were supported by a CIHR Training Grant in Genetics, Child Development and Health. We thank François Guillemot, David Anderson, Tak Mak, Tatsumi Hirata, Daniel Dufort, Masato Nakafuku, and Valerie Wallace for generously providing reagents or mice. We also thank Nicole Gruenig, Dawn Zinyk, Pierre Mattar, and Natasha Klenin for technical support.

The authors declare no competing financial interests.

${ }^{*}$ R.D. and G.W. contributed equally to this work.

Correspondence should be addressed to Carol Schuurmans at the above address. E-mail: cschuurm@ucalgary.ca. DOI:10.1523/JNEUROSCI.0614-13.2014

Copyright $\odot 2014$ the authors $\quad 0270-6474 / 14 / 340539-15 \$ 15.00 / 0$
(Smart and Smart, 1977; Wood et al., 1992; Marin-Padilla, 1998; Supèr et al., 1998). CR cells arise from three sites in the pallial margins: (1) medially, the cortical hem/choroid plexus; (2) rostrally, the pallial septum/rostrobulbar area; and (3) laterally, the ventral pallium (Takiguchi-Hayashi et al., 2004; Bielle et al., 2005; Yoshida et al., 2006; Zhao et al., 2006; García-Moreno et al., 2007; Imayoshi et al., 2008). Given their pallial origins, most CR cells are labeled in an Emx1-lineage trace (Gorski et al., 2002) and express Tbr1 (Hevner et al., 2003), both cortical-specific transcription factors. Many CR cells also express Reelin (Alcántara et al., 1998), a secreted glycoprotein that guides radial migration of neocortical neurons (Caviness, 1982; Howell et al., 1997).

While neocortical development has been well studied, much less is known about the three-layered piriform cortex. The piriform cortex is a central component of the olfactory system, which together with the olfactory epithelium (OE) and olfactory bulb $(\mathrm{OB})$ is responsible for detecting and processing odors. Superficial layer II and deep layer III of the piriform cortex contain glutamatergic projection neurons and interspersed GABAergic interneurons (Sarma et al., 2011), while layer I is a cell-sparse zone containing CR neurons and lateral olfactory tract (lot) guidepost cells. Lot cells guide innervation of the anterior piri- 
form cortex by OB mitral cells, the axons of which form the LOT (note that lot guidepost cells are distinguished from LOT axons by small and capital letters, respectively; Sato et al., 1998). We noted several striking similarities between lot cells (Sato et al., 1998; Tomioka et al., 2000) and CR neurons (Wood et al., 1992; Hevner et al., 2003; Takiguchi-Hayashi et al., 2004): both act as cellular guideposts for axonal tract formation, have a pallial origin, are among the earliest born cortical neurons (lot cells also differentiate between E9.5 and E11), and migrate tangentially from their pallial sites of origin to populate the piriform cortex (Sato et al., 1998; Tomioka et al., 2000). However, while CR cell differentiation is well understood, the factors that specify a lot cell identity, and more globally control neuronal fate specification in the piriform cortex, remain poorly characterized.

Here we demonstrate that the proneural basic helix-loop-helix (bHLH) transcription factors Neurog1 and Neurog2, which specify a neocortical projection neuron identity (Fode et al., 2000; Schuurmans et al., 2004), also specify piriform cortical neuronal identities. Specifically, Neurog1 and Neurog 2 are required in two differentiation waves-first acting in opposition to control lot cell differentiation, which we reveal are a subpopulation of CR neurons, the localization of which depends on $\operatorname{Trp} 73$, and later controlling the differentiation of layer II/III piriform cortical neurons.

\section{Materials and Methods}

Animals and genotyping. Animal procedures followed guidelines of the Canadian Council of Animal Care and were approved by the University of Calgary Animal Care Committee (Protocol AC11-0053), the Institutional Animal Care and Use Committee of State University of New York Upstate Medical University, and the Hospital for Sick Children Animal Care Committee. Embryos of either sex were used throughout. Neurog1 (Ma et al., 1998) and Neurog2 ${ }^{\text {GFP KI }}$ (Britz et al., 2006) mutant alleles were maintained on a CD1 background (Charles River) and genotyped as described (Ma et al., 1998; Britz et al., 2006). Lef/Tcf-lacZ transgenics were provided by Valerie Wallace and Daniel Dufort (Mohamed et al., 2004) and genotyped using forward (CCATCCAGAGACAAGCGAAGAC) and reverse (TTGAGGGGACGACGACAGT ATC) primers (35 cycles of $95^{\circ} \mathrm{C} / 1^{\prime}, 58^{\circ} \mathrm{C} / 1^{\prime}, 72^{\circ} \mathrm{C} / 1.5^{\prime}$, then final extension $\left.72^{\circ} \mathrm{C} / 10^{\prime}\right)$. TAp73 mutants were genotyped using the following primers: TAp73WT: CTGGTCCAGGAGGTGAGACTGAGGC; TAp73 Common: CTGGCCCTCTCAGCTTGTGCCACTTC, and TAp73Neo: GTGGGGGTGGGATTAGATAAATGCCTG (TAp73WT and TAp73 Common for wild-type allele, $1 \mathrm{~kb}$; and TAp73Neo and TAp73 Common for mutant allele, $1.2 \mathrm{~kb} ; 35$ cycles of $\left.94^{\circ} \mathrm{C} / 45 \mathrm{~s}, 65^{\circ} \mathrm{C} / 30 \mathrm{~s}, 72^{\circ} \mathrm{C} / 1.5 \mathrm{~min}\right) . \operatorname{Trp} 73$ ( $p 73)$ mutants were genotyped using three primer PCRs: $p 73-1$ : GGGCCATGCCTGTCTACAAGAA; p73-2: CCTTCTACACGGATGAGGTG; 7 73-3:GAAAGCGAAGGAGCAAAGCTG (wild type, 550 bp; mutant, $400 \mathrm{bp} ; 40$ cycles of $\left.94^{\circ} \mathrm{C} / 30 \mathrm{~s}, 64^{\circ} \mathrm{C} / 30 \mathrm{~s}, 72^{\circ} \mathrm{C} / 40 \mathrm{~s}\right)$. Reeler mutants (B6C3Fe a/a-Relnrl/+) were obtained from Jackson Laboratories and genotyped as described previously (D'Arcangelo et al., 1996).

Tissue processing, histology, and $\beta$-galactosidase histochemical staining. For histology, whole E18.5 heads were fixed in Bouin's solution, embedded in paraffin, and cut into $7 \mu \mathrm{m}$ sections, which were stained with hematoxylin and eosin as previously described (Fode et al., 1998). For all other tissue studies, embryos were fixed overnight in $4 \%$ paraformaldehyde (PFA) in $1 \times \mathrm{PBS}, \mathrm{pH} 7.4$, at $4^{\circ} \mathrm{C}$, washed in $1 \times \mathrm{PBS}$, and cryoprotected in $20 \%$ sucrose in $1 \times \mathrm{PBS}$ overnight at $4^{\circ} \mathrm{C}$ before embedding and freezing in Tissue Tek OCT (Sakura Finetek). Ten-micrometer cryosections were collected on Superfrost plus slides (Fisher Scientific). X-gal histochemical staining was performed on cryostat sections as follows. Sections were first washed $3 \times 10 \mathrm{~min}$ in lacZ wash buffer $(2 \mathrm{~mm} \mathrm{MgCl} /$ $0.01 \%$ sodium deoxycholate $/ 0.02 \%$ Nonidet-P $40 / 100 \mathrm{~mm}$ sodium phosphate, $\mathrm{pH} 7.3$ ) before staining overnight at $37^{\circ} \mathrm{C}$ in wash buffer containing $5 \mathrm{~mm}$ potassium ferrocyanide, $5 \mathrm{~mm}$ potassium ferricyanide, and $0.67 \mathrm{mg} / \mathrm{ml} \mathrm{X-gal} \mathrm{(Invitrogen).} \mathrm{Slides} \mathrm{were} \mathrm{then} \mathrm{washed} \mathrm{in} \mathrm{PBS,}$ rinsed in water, and allowed to dry before mounting in Permount (Fisher Scientific).
RNA in situ hybridization. RNA in situ hybridization was performed as previously described (Alam et al., 2005) using digoxygenin-labeled riboprobes that were generated using a $10 \times$ labeling mix according to the manufacturer's instructions (Roche Diagnostics). Riboprobes were generated from linearized plasmid templates as follows: Reln (EcoRI/T3), Trp73 (SalI/T3), Etv1 (SpeI/T7), Ctip2 (IMAGE 4457123; SalI/T7), Id2 (HindIII/T3), Dlx1 (XbaI/T3), Wnt7b (NcoI/SP6), mGluR1 (IMAGE 30536724; EcoRI/T3), and Dbxl (IMAGE 5718470; EcoRI/T3).

Immunostaining and imaging. Immunostaining was performed on 10 $\mu \mathrm{m}$ cryostat sections that were processed and collected as described above. Cryosections were blocked either in 10\% normal goat or donkey serum in $0.1 \%$ Triton X-100 in $1 \times$ PBS or in $1 \times$ Tris-buffered saline $(25$ $\mathrm{mm}$ Tris-HCl, $\mathrm{pH}$ 7.4, $0.14 \mathrm{M} \mathrm{NaCl}$ ). Primary antibodies included: rabbit anti-calretinin (1:500; Swant), mouse anti-Ascl1 (1:200; BD Biosciences), mouse anti-Neurog2 (1:20; gift from David Anderson), rabbit anti-Neurog2 (1:500; gift from Masato Nakafuku), rabbit anti-Neurog1 (1:500; gift from Jane Johnson), rabbit anti-GFP (1:500; Millipore Bioscience Research Reagents), sheep anti-GFP (1:750; Biogenesis), rabbit anti-Tbr1 (1:3000, Millipore Bioscience Research Reagents), mouse anti-Reelin (1:500; Millipore Bioscience Research Reagents), rabbit antiactivated caspase 3 (1:100; Promega), mouse anti-MAP2 (1:500; SigmaAldrich), rabbit anti-Pax6 (1:500; Covance), rabbit-anti-Trp73 (1:500; Bethyl Laboratories), and rat anti-lot1 (1:200; gift from Tatsumi Hirata). Species-specific secondary antibodies were conjugated to Alexa488 (1: 500; Invitrogen), Сy3 (1:500; Jackson Immunoresearch), or horseradish peroxidase (HRP). Sections were counterstained with DAPI $(4,6-$ diamidino-2-phenylindole, 1:10,000; Sigma-Aldrich) and mounted in AquaPolymount (Polysciences). DAB staining of HRP-conjugated antibodies was performed using the Vectastain $\mathrm{ABC}$ kit according to the manufacturer's instructions (Vector Laboratories).

DiI tracing. E18.5 brains were fixed for $2 \mathrm{~d}$ in $4 \%$ PFA in $1 \times \mathrm{PBS}$ at $4^{\circ} \mathrm{C}$. Carbocyanin DiI crystals (Invitrogen) were introduced into the $\mathrm{OB}$, and the brains were incubated at $37^{\circ} \mathrm{C}$ in $4 \%$ PFA in $1 \times$ PBS to allow dye diffusion for 2-3 weeks, followed by imaging.

In vitro electroporation and quantitation. The pCIG2-Neurog2 expression vector was previously described (Mattar et al., 2008). The Neurog1 cDNA was similarly PCR amplified and subcloned into pCIG2. Ex vivo electroporation and culture of E10.5 embryos were performed as previously described (Zimmer et al., 2010). Cell counts were performed on $\geq 3$ independent embryos and on three sections per embryo. Error bars reflect SEM. Student's $t$ tests were performed with $p$ values denoted as follows: ${ }^{*} p<0.05,{ }^{* *} p<0.01,{ }^{* *} p<0.005$.

\section{Results}

Neurog1 and Neurog2 are coexpressed in ventral pallial progenitors and derivative lineages in both the neocortex and piriform cortex

Neocortical progenitors undergo temporal identity transitions (Pearson and Doe, 2004), first giving rise to CR neurons, then sequentially generating glutamatergic pyramidal neurons in neocortical layers VI, V, IV, and finally II/III (fused in mouse; Takahashi et al., 1999). Neurog2 functions iteratively in this process, first promoting the differentiation of CR neurons (Imayoshi et al., 2008) and then functioning with Neurog1, a related proneural gene, to specify the glutamatergic identities of layer V/VI neurons (Fode et al., 2000; Schuurmans et al., 2004). Currently, it is not known whether Neurog1 also functions in CR development, nor is it known whether Neurog1 and Neurog2 specify neuronal identities in the three-layered piriform cortex, which is an evolutionarily more ancient structure. We addressed these two questions herein.

The piriform cortex is derived from the ventral pallium (Puelles et al., 2000; Hirata et al., 2002), which also serves as one of three CR cell progenitor domains (in addition to the pallial septum and cortical hem; Fig. 1A). Thus, first asking whether Neurog1 and Neurog2 were expressed in ventral pallial progenitors, we examined cortices between E10.5 and E12.5, the period when CR cells (Wood et al., 1992; Hevner et al., 2003; Takiguchi-Hayashi et al., 2004) and layer 


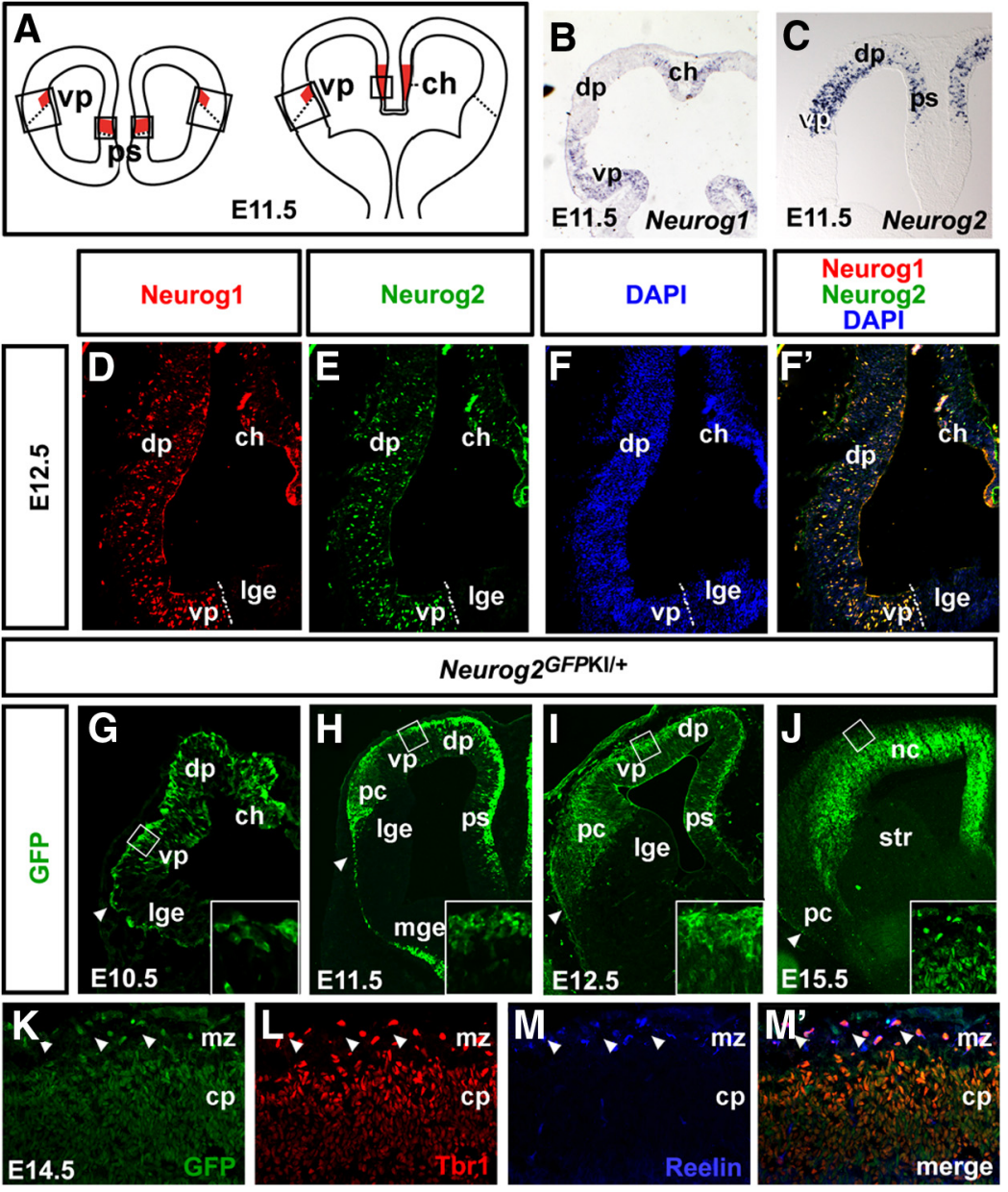

Figure 1. Neurog1 and Neurog2 are coexpressed in CR progenitors. $A$, Schematic representation of the three main sites of CR cell production. $\boldsymbol{B}, \boldsymbol{C}$, Distribution of Neurog $1(\boldsymbol{B})$ and Neurog2 $(\boldsymbol{C})$ transcripts in the E11.5 telencephalon. $\boldsymbol{D}-\boldsymbol{F}, \boldsymbol{F}^{\prime}$, Expression of Neurog1 $\left(\boldsymbol{D}, \boldsymbol{F}^{\prime}\right.$, red), Neurog2 $\left(\boldsymbol{E}, \boldsymbol{F}^{\prime}\right.$, green), and DAPI counterstain $\left(\boldsymbol{F}, \boldsymbol{F}^{\prime}\right.$, blue) in E12.5 telencephalon. The dotted lines mark the pallialsubpallial border. G-J, Expression of GFP in E10.5 (G), E11.5 (H), E12.5 (I), and E15.5 (J) Neurog2 ${ }^{\text {GFP KI/+ }}$ cortices. Insets are high-magnification images of the boxed areas in the preplate (E10.5-E12.5) and marginal zone (E15.5). Arrowhead in mark the pallial-subpallial border. $\boldsymbol{K}-\boldsymbol{M}, \boldsymbol{M}^{\prime}$, Coexpression of GFP $\left(\boldsymbol{K}, \boldsymbol{M}^{\prime}\right.$, green), $\operatorname{Tbr} 1\left(\boldsymbol{L}, \boldsymbol{M}^{\prime}\right.$, red), and Reelin $(\boldsymbol{M}, \boldsymbol{M})$ in E15.5 Neurog $2^{G F P ~ K 1 /+}$ neocortex. Arrowheads mark CR neurons coexpressing all three markers in the marginal zone. ch, Cortical hem; $c p$, cortical plate; dp, dorsal pallium; Ige, lateral ganglioniceminence; mge, medial ganglioniceminence; mz, marginal zone; $\mathrm{nc}$, neocortex; ps, pallial septum;str, striatum; vp, ventral pallium.

III piriform cortex neurons arise (Hirata et al., 2002). At E10.5 (data not shown) and E11.5, Neurog1 and Neurog2 transcripts (Fig. 1 B, C) and protein (data not shown) were detected in scattered pallial progenitors in a high-lateral to low-medial gradient, with elevated expression levels particularly evident in the ventral pallium, cortical hem, and pallial septum.

By E12.5, Neurog1 and Neurog2 were more broadly expressed in scattered progenitors throughout the pallial ventricular zone (VZ), including in the three sites of CR cell production (Fig. $1 D-F$; data not shown). Quantification of proneural expression in E12.5 CR progenitor domains revealed that Neurog1 (ventral pallium; $11.3 \pm 1.1 \%$ of $\mathrm{DAPI}^{+}$cells, $n=3,1372$ cells; cortical hem: $6.9 \pm 0.2 \%$ of DAPI $^{+}$cells; $n=3,2980$ cells) was expressed in fewer CR progenitors than Neurog2 (ventral pallium; $24.4 \pm$ $6.1 \%$ of DAPI $^{+}$cells, $n=3,1372$ cells; cortical hem: $11.6 \pm 0.5 \%$ of DAPI ${ }^{+}$cells; $n=3,2980$ cells). Nevertheless, the vast majority of Neurog $1^{+}$progenitors coexpressed Neurog2 (ventral pallium: $97.8 \pm 1.5 \%, n=3,1372$ cells; cortical hem: $89.1 \pm 4.3 \%, n=3$, 2980 cells), indicating that these proneural genes are coexpressed in a common lineage.
Given that Neurog $2^{+}$pallial progenitors largely encompass the Neurog $1^{+}$ population, we performed short-term lineage tracing in Neurog $2^{G F P \mathrm{KI} /+}$ cortices to capture both lineages, taking advantage of GFP perdurance in derivative neurons. In E10.5-E15.5 Neurog $2^{G F P \mathrm{KI} /+}$ cortices, $\mathrm{GFP}^{+}$cells were detected in the neocortical and piriform cortical marginal zones (Fig. 1G-J), where CR cells reside. GFP expression was also detected in the germinal zones and mantle layers of the neocortex and piriform cortex (Fig. $1 G-J, K, M^{\prime}$ ). Within the E14.5 Neurog $2^{G F P \mathrm{KI} /+}$ marginal zone, the vast majority of $\mathrm{GFP}^{+}$cells coexpressed Reelin, a CR cell marker (Alcántara et al., 1998), and Tbr1, a corticalspecific T-box protein (Hevner et al., 2003; Fig. $1 K-M^{\prime}$ ). This is consistent with the pallial identity of CR neurons (Hevner et al., 2003) and with our previous shortterm lineage-tracing experiments in E11.5 Neurog $2^{\text {GFP KI/+ }}$ neocortices (Dixit et al., 2011b).

Thus, Neurog $2^{+}$pallial progenitors, which largely encompass the Neurog $1^{+}$ pallial progenitor pool, give rise to $\mathrm{CR}$ cells that populate the marginal zones of both the piriform cortex and neocortex as well as the mantle zones of both structures.

\section{Neurog 2 single and Neurog1 and Neurog2 double mutants display early and spatially distinct deficiencies in CR cells}

It was previously reported that fewer CR cells are generated in E12.5 and E14.5 Neu$\operatorname{rog} 2^{-1-}$ neocortices (Imayoshi et al., 2008). However, this study did not address $\mathrm{Neu}$ rog 2 function in CR cells in the piriform cortex, nor did it address whether Neurog1 also contributes to CR cell development. We therefore compared CR cell numbers in Neurog1 and Neurog 2 single mutants as well as Neurog1 and Neurog2 double mutants (hereafter Neurog1/2) at E12.5, when CR differentiation is mostly complete. We first analyzed the neocortical preplate for Reln expression. Compared with E12.5 wild-type neocortices (111.4 $\pm 7.0 \mathrm{Reln}^{+}$cells/ field; $n=3$; Fig. $\left.2 A, A^{\prime}, M\right)$, the number of $\operatorname{Reln}^{+}$cells was reduced to a similar extent (1.3-fold and 1.4-fold, respectively) in Neurog $2^{-1-}$ $\left(88.6 \pm 5.0\right.$ Reln $^{+}$cells/field; $n=3 ; p<0.05$; Fig. $\left.2 C, C^{\prime}, M\right)$ and Neurog $1^{-1-} ;$ Neurog $2^{-1-}$ (hereafter referred to as Neurog1/2 ${ }^{-1-}$ ) neocortices (75.4 $\pm 5.9 \mathrm{Reln}^{+}$cells/field; $n=2$; $p<0.01$; Fig. $\left.2 D, D^{\prime}, M\right)$. In contrast, 1.3-fold more Reln $^{+}$cells were detected in the Neurog $1^{-1-}$ neocortical preplate $\left(143.3 \pm 6.0 \mathrm{Reln}^{+}\right.$cells/field; $n=3$; $p<0.01$; Fig. $2 B, B$ ',M). Notably, the increase in Reln $^{+} \mathrm{CR}$ cells in Neurog $1^{-1-}$ neocortices is consistent with our previous demonstration that E10.5-E12.5 Neurog1 ${ }^{-1-}$ neocortices undergo precocious neurogenesis, although these ectopic neurons were not previously identified as CR cells (Fode et al., 2000; Mattar et al., 2004). Strikingly, precocious neurogenesis is also observed in Neurog1/2 $2^{-1-}$ neocortices (Fode et al., 2000; Mattar et al., 2004), yet these neurons do not acquire a CR cell fate (Fig. 2D, D',M). We 
interpret these results in the following way. While either Neurog1 or Neurog2 can specify a CR cell identity, Neurog1 has an added role, which is to slow down the rate of early cortical neurogenesis. Consistent with this interpretation, Neurog $2^{-1-}$ CR cell loss is restricted to dorsomedial domains (Fig. 2C), where Neurog1 expression is lost (Fode et al., 2000), such that this region is equivalent to a Neurog1/2 double mutant.

To further substantiate the roles of $\mathrm{Neu}$ rog1 and Neurog2 in CR cell genesis, we also analyzed Tbrl expression, which labels CR neurons as well as deep-layer cortical neurons (Hevner et al., 2003). In E12.5 embryos of all genotypes, Tbr1 was expressed in the neocortical and piriform cortical preplates, albeit at higher levels in Neurog $1^{-1-}$ cortices, which produce more CR neurons, and at lower levels in Neurog $2^{-1-}$ and Neurog1/ $2^{-1-}$ cortices, where CR cell numbers are reduced (Fig. $2 E-H^{\prime}$ ). In addition, Tbr1 was expressed in a wedge of cells adjacent to the lateral ganglionic eminence (LGE), demarcating the nascent piriform cortex, in all genotypes, except Neurog1/2 ${ }^{-1-}$ double mutants (Fig. 2E-H). Similar results were obtained when monitoring Trp73 expression, which labels CR cells derived from the pallial septum and cortical hem (Meyer et al., 2002, 2004): 1.4-fold more $\operatorname{Trp} 73^{+}$cells in the Neurog $1^{-1-}$ preplate $(62.2 \pm 3.6$ Trp $73^{+}$cells/field; $n=3 ; p<0.0001$; Fig. $\left.2 J, J^{\prime}, N\right)$ compared with wild type (44.5 \pm $2.2 \operatorname{Trp} 73^{+}$cells/field; $n=3$; Fig. $\left.2 I, I^{\prime}, N\right)$. Conversely, $\operatorname{Trp} 73^{+}$cell numbers were reduced 1.9-fold and 2.7-fold in Neu$\operatorname{rog} 2^{-1-}\left(23.2 \pm 2.0 \operatorname{Trp} 73^{+}\right.$cells/field; $n=3 ; p<0.0001$; Fig. $\left.2 K, K^{\prime}, N\right)$ and Neu$\operatorname{rog} 1 / 2^{-1-}\left(16.6 \pm 2.1 \operatorname{Trp}^{-} 3^{+}\right.$cells/field; $n=2$; $p<0.0001$; Fig. $\left.2 L, L^{\prime}, N\right)$ neocortices, respectively. Moreover, in the nascent piriform cortex, where $\operatorname{Tr} p 73^{+}$cells normally accumulate in a lateral wedge, a striking loss of $\operatorname{Trp} 73^{+}$CR cells was observed specifically within Neurog $1 / 2^{-1-}$ embryos (Fig. 2L).

Thus, CR cell differentiation in both the neocortex and piriform cortex requires either Neurog1 or Neurog2. In addition, Neurog1 has an additional role, which is to slow down the genesis of early-born cortical neurons, including CR cells, ensuring that appropriate numbers of these early-born neurons are generated.

Defects in CR cell differentiation persist in later stage Neurog $2^{-/-}$and Neurog1/ $2^{-1-}$ neocortices and piriform cortices

The presence of fewer CR cells in E12.5 Neurog $2^{-1-}$ and Neurog1/ $2^{-1-}$ cortices could be due to a delay rather than a reduction in differentiation. To address this possibility, we examined Neurog1 and Neurog2 single and Neurog1/2 double mutants at E15.5, $3 \mathrm{~d}$ after

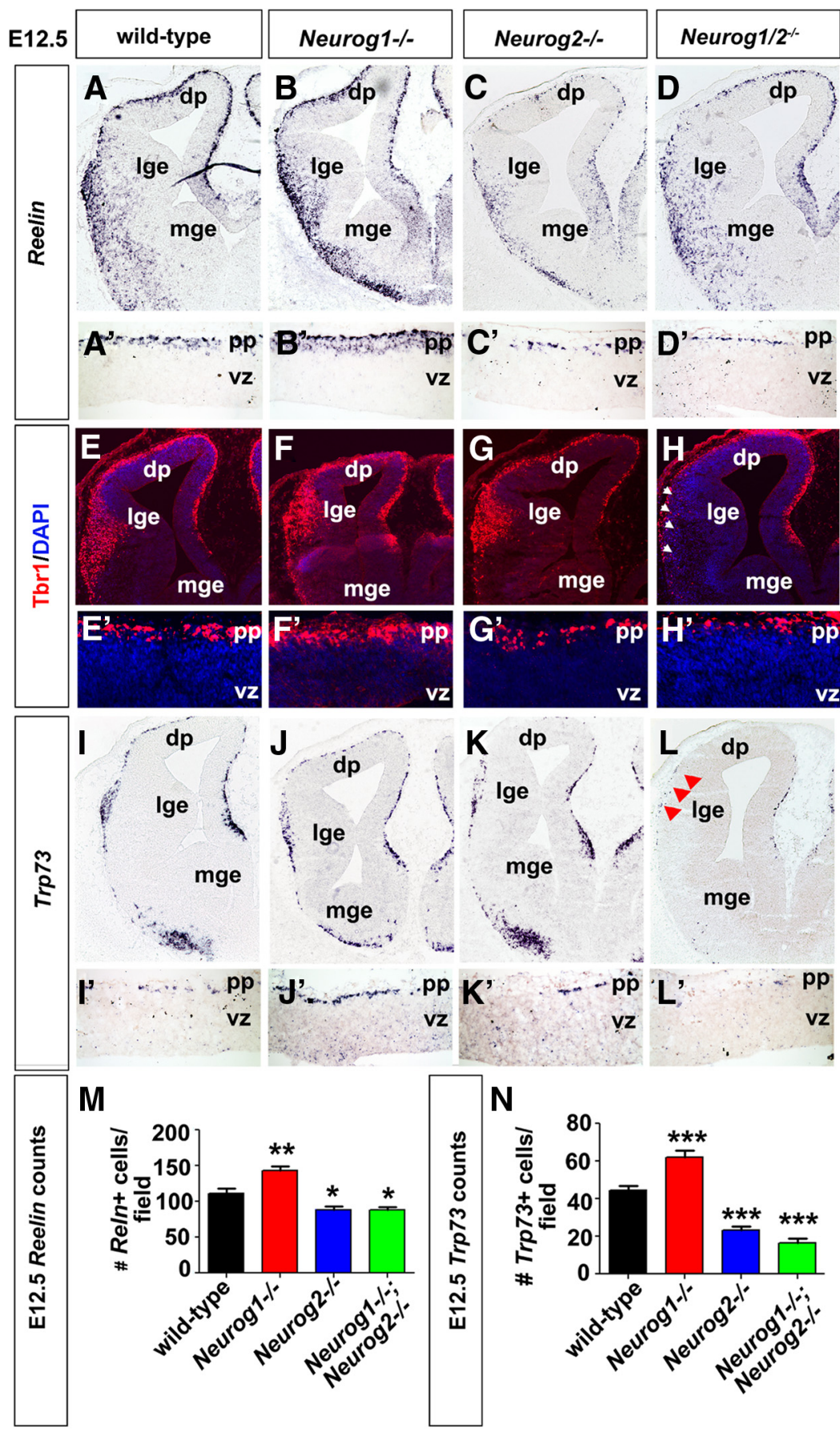

Figure 2. Reduced CR cell differentiation in E12.5 Neurog $2^{-/-}$and Neurog $1 / 2^{-1-}$ neocortices and Neurog $1 / 2^{-/-}$piriform cortex. $\boldsymbol{A}-\boldsymbol{D}^{\prime}$, Expression of Reelin in E12.5 wild-type $(\boldsymbol{A}, \boldsymbol{A})$, Neurog $1^{-1-}(\boldsymbol{B}, \boldsymbol{B})$, Neurog $2^{-1-}(\boldsymbol{C}, \boldsymbol{C})$, and Neurog $1 / 2^{-1-}(\boldsymbol{D}, \boldsymbol{D})$ cortices. $\boldsymbol{A}^{\prime}-\boldsymbol{D}^{\prime}$ are high-magnification images of $\boldsymbol{A}-\boldsymbol{D}$ in the neocortical preplate. $\boldsymbol{E}-\boldsymbol{H}^{\prime}$, Expression of $\mathrm{Tbr} 1$ in $E 12.5$ wild-type $(\boldsymbol{E}$, $\left.\boldsymbol{E}^{\prime}\right)$, Neurog $1^{-1-}(\boldsymbol{F}, \boldsymbol{F})$, Neurog $2^{-1-}(\boldsymbol{G}, \boldsymbol{G})$, and Neurog $1 / 2^{-1-}(\boldsymbol{H}, \boldsymbol{H})$ cortices. $\boldsymbol{E}^{\prime}-\boldsymbol{H}^{\prime}$ are high-magnification images of neocortical preplate in $\boldsymbol{E}-\boldsymbol{H}$. Arrowheads in $\boldsymbol{H}$ mark the loss of $\mathrm{Tbr} 1^{+} \mathrm{CR}$ cells in the presumptive piriform cortex. $\boldsymbol{I}-\boldsymbol{L}^{\prime}$, Expression of Trp73 in E12.5 wild-type $(\boldsymbol{I}, \boldsymbol{I})$, Neurog $1^{-1-}(\boldsymbol{J}, \boldsymbol{J})$, Neurog $2^{-1-}(\boldsymbol{K}, \boldsymbol{K})$, and Neurog $1 / 2^{-I-}(\boldsymbol{L}, \boldsymbol{L})$ cortices. $\boldsymbol{I}^{\prime}-\boldsymbol{L}^{\prime}$ are highmagnification images of neocortical preplate in $I-L$. Arrowheads in $L$ mark the loss of $T r p 73^{+}$CR cells in the presumptive piriform cortex. $\boldsymbol{M}, \boldsymbol{N}$, Quantitation of the number of Reelin ${ }^{+}(\boldsymbol{M})$ and $\operatorname{Trp}_{3} 3^{+}(\boldsymbol{N})$ cells in the neocortex of embryos for each genotype. Error bars in $\boldsymbol{M}$ and $\boldsymbol{N}$ represent SEM. Student's $t$ tests were performed comparing all genotypes individually to wild type with $p$ values denoted as follows: ${ }^{*} p<0.05,{ }^{* *} p<0.01,{ }^{* * *} p<0.005$. dp, Dorsal pallium; Ige, lateral ganglionic eminence; mge, medial ganglionic eminence; $p p$, preplate; $v z$, ventricular zone.
CR cell differentiation is normally complete. At E15.5, Reln was expressed in a relatively continuous layer in the neocortical marginal zones of wild-type and Neurog $1^{-1-}$ neocortices, whereas distinct gaps in Reln expression were detected in Neurog $2^{-1-}$ and Neurog1/ 

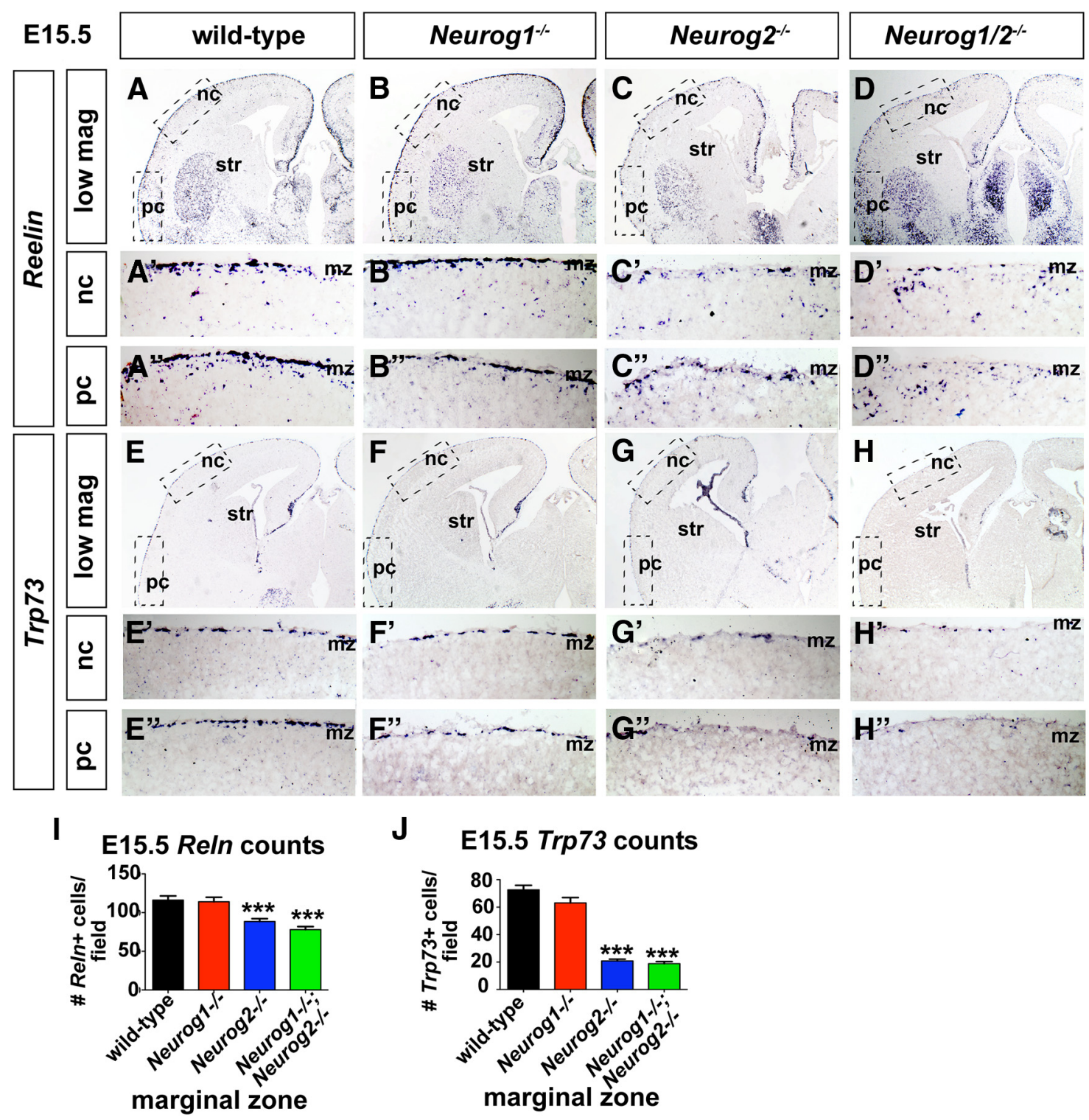

Figure 3. Defects in CR cell differentiation in the E15.5 Neurog $2^{-1-}$ neocortex and Neurog $1 / 2^{-1-}$ neocortex and piriform cortex. $\boldsymbol{A}-\boldsymbol{D}^{\prime \prime}$, Expression of Reelin in E15.5 wild-type $\left(\boldsymbol{A}-\boldsymbol{A}^{\prime \prime}\right)$, Neurog $1^{-1-}\left(\boldsymbol{B}-\boldsymbol{B}^{\prime \prime}\right)$, Neurog2 $2^{-/-}\left(\boldsymbol{C}-\boldsymbol{C}^{\prime \prime}\right)$, and Neurog1/2 ${ }^{-1-}\left(\boldsymbol{D}-\boldsymbol{D}^{\prime \prime}\right)$ cortices. $\boldsymbol{A}^{\prime}-\boldsymbol{D}^{\prime}$ are high-magnification images of boxed neocortical regions in $\boldsymbol{A}-\boldsymbol{D}$. $\boldsymbol{A}^{\prime \prime}-\boldsymbol{D}^{\prime \prime}$ are high-magnification images of boxed piriform cortex regions in $\boldsymbol{A}-\boldsymbol{D}$. $\boldsymbol{E}-\boldsymbol{H}^{\prime \prime}$, Expression of Trp73 in E15.5 wild-type $\left(\boldsymbol{E}-\boldsymbol{E}^{\prime \prime}\right)$, Neurog $1^{-/-}\left(\boldsymbol{F}-\boldsymbol{F}^{\prime \prime}\right)$, Neurog $2^{-/-}\left(\boldsymbol{G}-\boldsymbol{G}^{\prime \prime}\right)$, and Neurog1/2 ${ }^{-/-}\left(\boldsymbol{H}-\boldsymbol{H}^{\prime \prime}\right)$ cortices. $\boldsymbol{E}^{\prime}-\boldsymbol{H}^{\prime}$ are high-magnification images of boxed neocortical regions in $\boldsymbol{E}-\boldsymbol{H}$. $\boldsymbol{E}^{\prime \prime}-\boldsymbol{H}^{\prime \prime}$ are high-magnification images of boxed piriform cortex regions in $\boldsymbol{E}-\boldsymbol{H}$. $\boldsymbol{I}, \boldsymbol{J}, \mathbf{Q}$ uantitation of the number of Reelin ${ }^{+}(\boldsymbol{I})$ and $\operatorname{Trp}_{3}{ }^{+}(\boldsymbol{J})$ cells per field in the marginal zone (i.e., CR cells). Error bars represent SEM. Student's $t$ tests were performed comparing all genotypes individually to wild type with $p$ values denoted as follows: ${ }^{*} p<0.05,{ }^{* *} p<0.01,{ }^{* * *} p<0.005$. mz, Marginal zone; nc, neocortex; $p c$, piriform cortex; str, striatum.

$2^{-1-}$ mutants (Fig. 3A-D'). Accordingly, quantitation of Reln ${ }^{+} \mathrm{CR}$ cells in the marginal zone revealed 1.3-fold and 1.5-fold reductions, respectively, in Neurog $2^{-1-}\left(88.6 \pm 3.6 \mathrm{Reln}^{+}\right.$cells/field; $n=3 ; p=$ $0.0002)$ and Neurog1/2-1- $\left(78.1 \pm 3.8\right.$ Reln $^{+}$cells/field; $n=2 ; p<$ $0.0001)$ neocortical marginal zones compared with wild-type $\left(116.2 \pm 5.4\right.$ Reln $^{+}$cells/field; $n=3$; Fig. 3I). Neurog1 ${ }^{-1-}$ CR numbers had normalized by E15.5 and were not significantly different than in wild-type neocortices (114.1 $\pm 5.8 \mathrm{Reln}^{+}$cells/field; $n=3$; $p=0.79$; Fig. $3 I)$. A similar result was observed when analyzing $\operatorname{Trp}_{73}{ }^{+}$CR cell numbers, which were reduced 3.4-fold and 3.8-fold, respectively, in Neurog $2^{-1-}\left(20.8 \pm 1.3 \mathrm{Trp} 73^{+}\right.$cells/field; $n=3$; $p<0.0001$; Fig. $3 G, G, J)$ and Neurog $1 / 2^{-1-}\left(18.8 \pm 1.5 \operatorname{Trp} 73^{+}\right.$ cells/field; $n=2$; $p<0.0001$; Fig. $\left.3 H, H^{\prime}, J\right)$ neocortical marginal zones compared with wild-type embryos $\left(72.6 \pm 3.3 \operatorname{Trp} 73^{+}\right.$cells/ field; $n=3$; Fig. $3 E, E$, J), while Neurog $1^{-1-}$ embryos had normal numbers of $\operatorname{Trp} 73^{+}$cells $\left(63.1 \pm 3.9 \operatorname{Tr} p 73^{+}\right.$cells/field; $n=3 ; p=$
0.07; Fig. $3 F, F, J)$. Moreover, similar to observations made at E12.5, almost no CR cells were detected in the presumptive piriform cortex of Neurog $1 / 2^{-1-}$ embryos (Fig. 3D", $H^{\prime \prime}$ ), whereas CR cells lined the marginal zone of the piriform cortex in all other genotypes (Fig. $\left.3 A^{\prime \prime}-C^{\prime \prime}, E^{\prime \prime}-G^{\prime \prime}\right)$.

The reduction in CR cell number in Neurog $2^{-1-}$ and $\mathrm{Neu}$ $\operatorname{rog} 1 / 2^{-1-}$ cortices thus persists at E15.5, and hence is unlikely to be due to a delay in CR cell genesis. Moreover, the original increase in CR cell number observed in E12.5 Neurog $1^{-1-}$ cortices is rectified by E15.5, indicating that Neurog1 is only required to delay cortical neurogenesis at early developmental stages.

Neurog2 is sufficient to induce CR cell differentiation while Neurog1 limits the formation of neocortical CR cells

The loss of CR cells in Neurog $2^{-1-}$ and Neurog $1 / 2^{-1-}$ cortices could arise if the medial signaling domains from which some CR 
cells arise are defective (Hanashima et al., 2007; Griveau et al., 2010; Zimmer et al., 2010), or if Neurogl and Neurog2 function as instructive determinants of a CR cell fate. To distinguish between these possibilities, we first examined marker expression in the Fgf-rich pallial septum (Bielle et al., 2005; Zimmer et al., 2010), Wnt/ Bmp-rich cortical hem (Takiguchi-Hayashi et al., 2004; Yoshida et al., 2006; GarcíaMoreno et al., 2007; Imayoshi et al., 2008), and Egf-rich ventral pallium (Assimacopoulos et al., 2003). In E12.5 Neurog1 and Neurog2 single and Neurog1/2 double mutant cortices, we observed normal patterns of expression of $F g f 8 / 17$ in the pallial septum (data not shown), Wnt3a in the cortical hem (Fig. 4A-D; Imayoshi et al., 2008), and $D b \times 1$ in the ventral pallium (Fig. 4E-H). CR cell progenitor domains are thus properly established in $\mathrm{Neu}$ $\operatorname{rog} 2^{-1-}$ and Neurog $1 / 2^{-1-}$ cortices.

We next asked whether Neurog1 and Neurog2 could function as instructive determinants of a CR cell fate. Consistent with this idea, Neurog2 was previously shown to promote ectopic Reelin expression when misexpressed in the E9.5 choroid plexus (Imayoshi et al., 2008). Here we asked whether Neurog1 and Neurog2 were sufficient to promote some or all aspects of a CR cell identity when misexpressed in E10.5 pallial progenitors. Expression vectors for Neurog1 or $\mathrm{Neu}$ rog 2 and a pCIG2 vector control, all expressing GFP, were introduced into the E10.5 pallium via in utero electroporation (Dixit et al., 2011a). After $2 \mathrm{~d}$ of in vitro explant culture, cortices were harvested and assessed for the induction of $\mathrm{CR}$ marker expression (Fig. 4I-M). Consistent with the Imayoshi et al. (2008) study, Neurog2 was sufficient to induce ectopic Reelin expression in the E10.5 pallium (3.0-fold increase; control: $13.4 \pm 2.9 \%$ Reelin ${ }^{+} \mathrm{GFP}^{+} / \mathrm{GFP}^{+}$cells; $n=4 ; 567$ cells; Neurog2: $40.5 \pm 4.8 \%$ Reelin $^{+} \mathrm{GFP}^{+} /$ $\mathrm{GFP}^{+} ; n=3 ; 1469$ cells; $p<0.005$; Fig. $4 I-M, N)$. In contrast, Neurog1 did not induce ectopic Reelin expression and, moreover, Neurog1 inhibited the ability of Neurog2 to induce a CR fate when the two genes were coelectroporated (2.3-fold decrease; Neurog1: $8.1 \pm 3.7 \%$ Reelin ${ }^{+} \mathrm{GFP}^{+}$/ $\mathrm{GFP}^{+}$cells; $n=3 ; 79$ cells; Neurog1 plus Neurog2: $18.0 \pm 4.6 \%$ Reelin $^{+} \mathrm{GFP}^{+}$/ $\mathrm{GFP}^{+} ; n=3 ; 757$ cells; Fig. $4 N$ ). In contrast, neither Neurog1 nor Neurog2 were sufficient to induce the expression of Trp73 (Fig. 4P), even though loss-of-function studies indicate that these proneural genes are required for the generation of $\operatorname{Trp} 73^{+} \mathrm{CR}$ neurons (Figs. 2, 3).
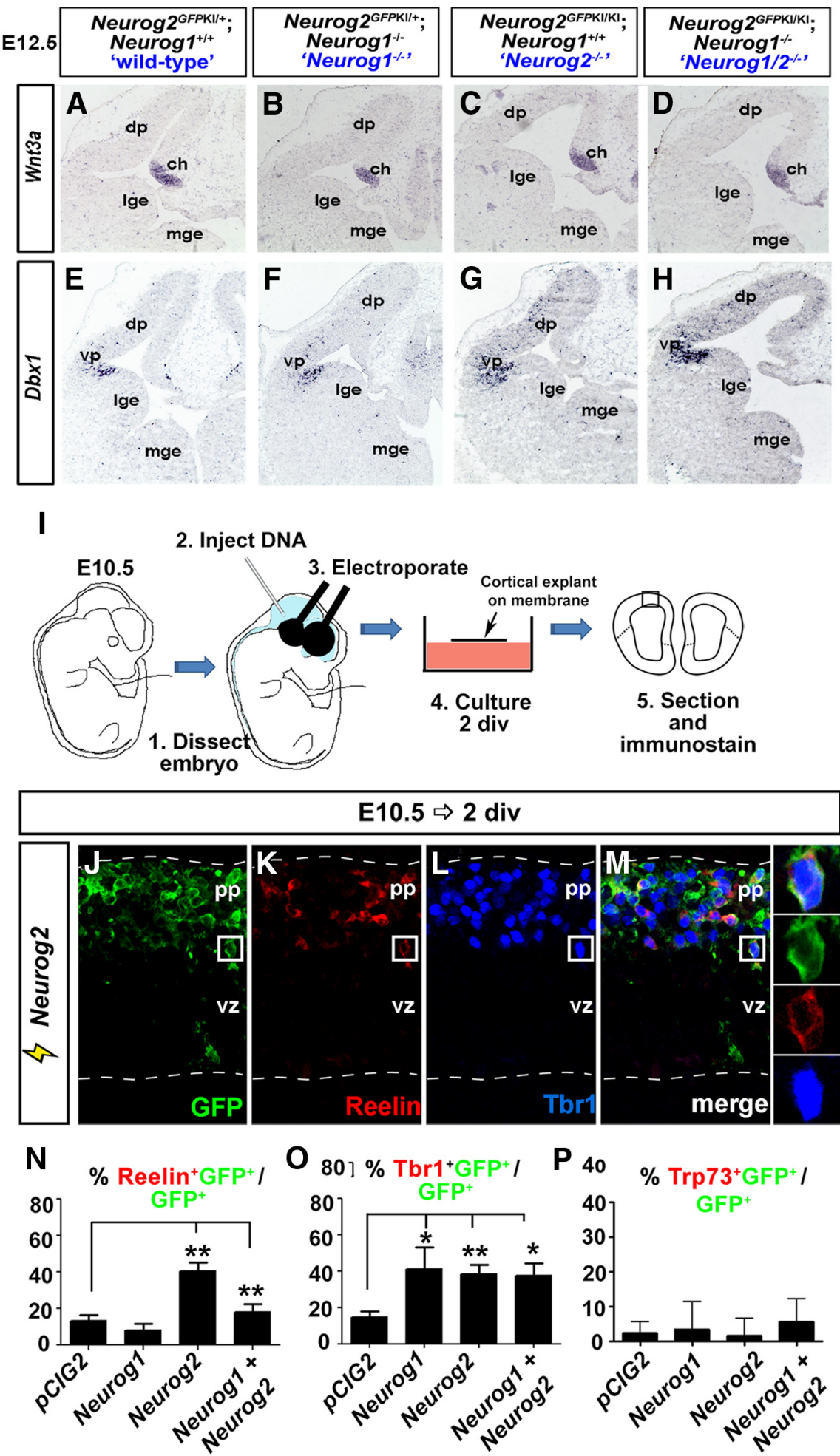

Figure 4. Neurog1 and Neurog2 are sufficient to induce the expression of a subset of $(R$ markers. $\boldsymbol{A}-\boldsymbol{H}$, Expression of

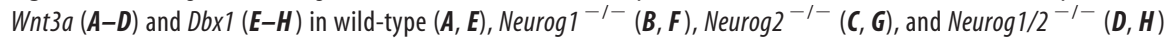
E12.5 cortices. I, Schematic representation of in vitro electroporation protocol: expression constructs were injected into the E10.5 mouse telencephalon, followed by dissection of the dorsal telencephalon, embryo culture for 2 DIV, and analysis. $J-M$, Misexpression of Neurog2-IRES-GFP in E10.5 cortices, followed after 2 DIV by immunolabeling to visualize expression of GFP ( $\boldsymbol{J}, \boldsymbol{M}$, green), Reelin $(\boldsymbol{K}, \boldsymbol{M}$, red), and $\operatorname{Tbr} \mathbf{1}(\boldsymbol{L}, \boldsymbol{M}$, blue). Boxes to the right of $\boldsymbol{M}$ are high-magnification images of the boxed areas in $\boldsymbol{J}-\boldsymbol{M} . \boldsymbol{N}-\boldsymbol{P}$, Quantitation of the percentage of GFP ${ }^{+}$electroporated cells expressing Reelin $(\boldsymbol{N}), \mathrm{Tbr}^{1}(\mathbf{0})$, or Trp73 $(\boldsymbol{P})$. Error bars represent SEM. Student's $t$ tests were performed comparing all genotypes individually to wild type with $p$ values denoted as follows: ${ }^{*} p<0.05,{ }^{* *} p<0.01,{ }^{* * *} p<0.005$. ch, Cortical hem; div, days in vitro; dp, dorsal pallium; Ige, lateral ganglionic eminence; mge, medial ganglionic eminence; $p p$, preplate; vz, ventricular zone; vp, ventral pallium. 


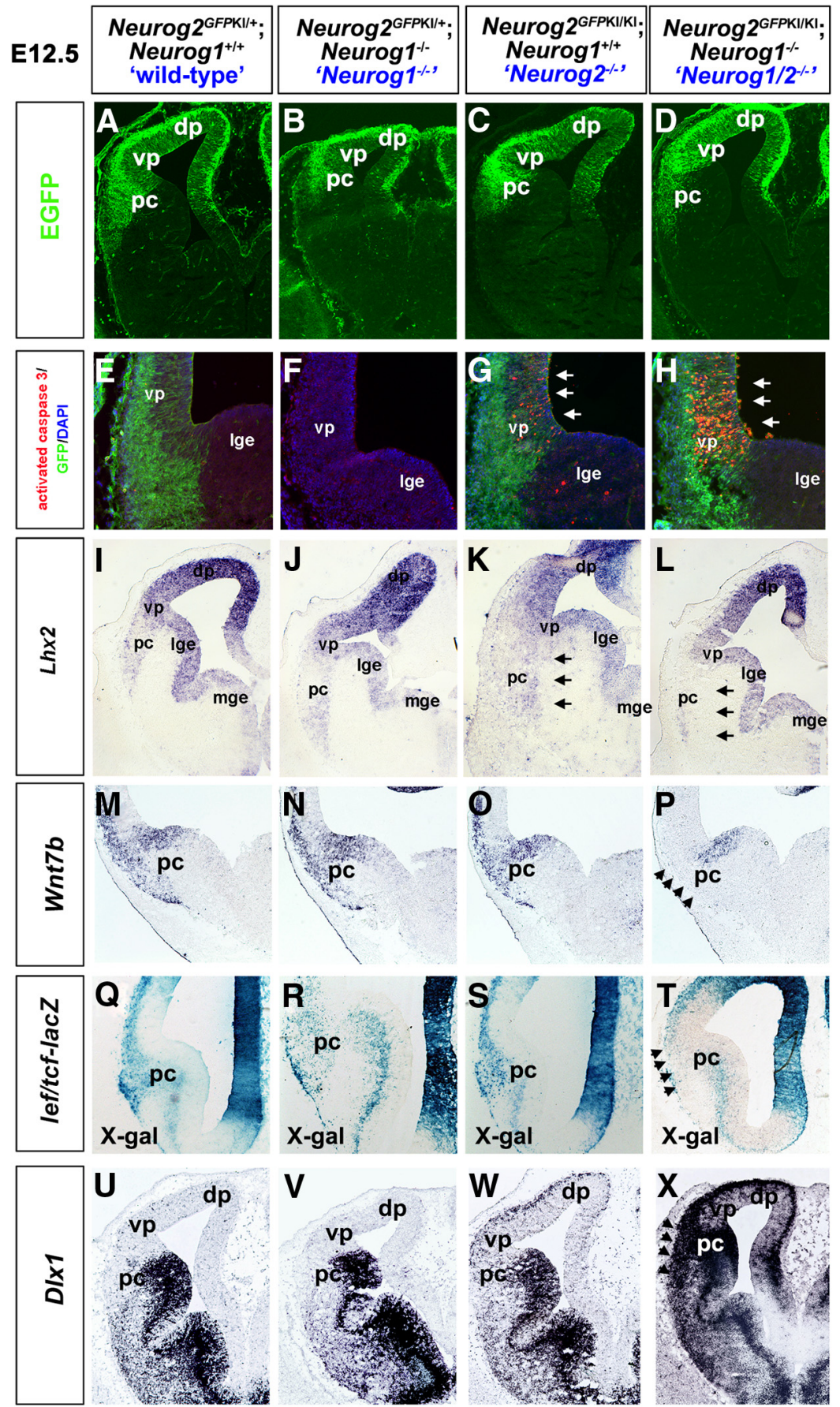

Figure 5. Early defects in cell fate specification in the ventral pallium and presumptive piriform cortex in Neurog $1 / 2^{-1-}$ embryos. $\boldsymbol{A}-\boldsymbol{H}$, Expression of GFP $(\boldsymbol{A}-\boldsymbol{D})$ and activated caspase $3\left(\boldsymbol{E}-\boldsymbol{H}\right.$, red) in E12.5 Neurog $2^{G F P ~ K I+/-}$ heterozygotes ("wildtype"; $\boldsymbol{A}, \boldsymbol{E})$, Neurog $1^{-1-}$ mutants carrying one copy of the Neurog $2^{G F P K I}$ allele $(\boldsymbol{B}, \boldsymbol{F})$, Neurog $2^{G F P K / K I}$ mutants $(\boldsymbol{C}, \boldsymbol{G})$, and Neurog $1^{-I-} ;$;Neurog $2^{G F P ~ K I / K I}$ double mutants (Neurog $1 / 2^{-I-} ; \mathbf{D}, \boldsymbol{H}$ ). Arrowheads in $\boldsymbol{G}$ and $\boldsymbol{H}$ mark elevated levels of apoptosis in the Neurog $2^{-I-}$ and Neurog $1 / 2^{-I-}$ ventral pallium. $\boldsymbol{I - P}$, Expression of $L$ hx $2(\boldsymbol{I}-\boldsymbol{L})$ and $W n t 7 b(\boldsymbol{M}-\boldsymbol{P})$ in E12.5 wild-type $(\boldsymbol{I}, \boldsymbol{M})$, Neurog $1^{-/-}(\boldsymbol{J}, \boldsymbol{N})$, Neurog $2^{-1-}(\boldsymbol{K}, \mathbf{0})$, and Neurog $1 / 2^{-/-}(\boldsymbol{L}, \boldsymbol{P})$ cortices. Arrowheads in $\boldsymbol{L}$ and $\boldsymbol{P}$ mark reduced expression of Lhx2 and Wnt7b in the double-mutant ventral pallium. Q- $\boldsymbol{T}, \mathrm{X}$-gal staining (blue) of E12.5 wild-type (Q), Neurog $1^{-1-}(\boldsymbol{R})$, Neurog $2^{-l-}(\boldsymbol{S})$, and Neurog $1 / 2^{-/-}(\boldsymbol{T})$ cortices, all from embryos carrying a lef/tcf-lacZ transgene. Arrowhead in $\boldsymbol{I}$ marks reduced X-gal staining. $\boldsymbol{U}-\boldsymbol{X}$, Expression of DlX1 in E12.5 wild-type $(\boldsymbol{U})$, Neurog $1^{-1-}(\boldsymbol{V})$, Neurog $2^{-1-}(\boldsymbol{W})$, and Neurog 1/2 $(\boldsymbol{X})$ cortices. Arrowhead in $X$ marks ectopic D/x 1 expression in double mutants. dp, Dorsal pallium; Ige, lateral ganglionic eminence; $\mathrm{pc}$, piriform cortex; vp, ventral pallium.

The inability of Neurog1 to promote a CR cell fate is not at first glance consistent with our loss-of-function studies, which suggest that Neurog1 can promote a CR cell fate in the absence of Neurog2. One possibility is that Neurog1 can induce some aspects of a $\mathrm{CR}$ cell fate, such as a cortical-specific neuronal identity, and not subtypespecific CR pathways, a mode of action that would be consistent with Neurogl's partial fate specification properties in the OE (Cau et al., 2002). To test this model, we asked whether Neurog1 and Neurog2 could induce the expression of Tbr1, a cortical identity marker. In striking contrast to Reelin, both Neurog1 and Neurog2 induced ectopic Tbr 1 expression whether expressed together or apart (2.8-fold, 2.6fold, and 2.5-fold increases respectively; control vector: $14.8 \pm 3.0 \% \mathrm{Tbr}^{+} \mathrm{GFP}^{+}$/ $\mathrm{GFP}^{+} ; n=4 ; 251$ cells; Neurog1: $41.3 \pm$ $12.0 \% \mathrm{Tbr}^{+} \mathrm{GFP}^{+} / \mathrm{GFP}^{+} ; n=3 ; 140$ cells; $p<0.05$ vs pCIG2; Neurog2: $38.6 \pm$ $4.9 \% \mathrm{Tbr}^{+} \mathrm{GFP}^{+} / \mathrm{GFP}^{+} ; n=3 ; 923$ cells; $p<0.005$ vs pCIG2; Neurog1 plus Neurog2: $37.7 \pm 6.6 \%$ Tbr $1^{+} \mathrm{GFP}^{+} /$ $\mathrm{GFP}^{+} ; n=3 ; 806$ cells; $p<0.05$ vs $\mathrm{pCIG} 2$; Fig. 4O).

Thus, while Neurog2 is sufficient to promote the expression of cortical and some CR cell identity markers in early pallial progenitors, as previously shown in the choroid plexus (Imayoshi et al., 2008), Neurog1 is only sufficient to induce a cortical identity, at least in the cellular context and time frame tested. Moreover, Neurog1 impedes Neurog2's ability to induce CR marker expression, consistent with a role for this factor in controlling the rate of early CR cell production.

Early defects in cell fate specification and not migration in the Neurog $1 / 2^{-1-}$ piriform cortex

Neurog2 has sequential functions in the neocortex: first promoting a CR identity and later specifying deep-layer neocortical cell fates. We thus asked whether $\mathrm{Neu}$ rog1 and Neurog2 have similar sequential functions in the ventral pallium/piriform cortex. After forming CR cells, ventral pallial progenitors give rise to neurons in the piriform cortex, with layer I lot cells differentiating between E10 and E11, followed by deep-layer III neurons at E12, and layer II neurons arising between E13 and E14 (de Carlos et al., 1996; Tomioka et al., 2000; Hirata et al., 2002; Vyas et al., 2003). To first determine whether Neurog2-expressing progenitors in the ventral pallium populate the piriform cortex, we examined GFP expression in E12.5 "wild-type" (i.e., Neurog $2^{G F P K I /+}$ heterozygous) and Neurog1 and Neurog2 single and double mutant embryos carrying a Neurog $2^{G F P \mathrm{KI}}$ allele (Fig. 5A-D). In E12.5 Neurog $2^{G F P \mathrm{KI}+/-}$ heterozygotes, $\mathrm{GFP}^{+}$cells emanated from the ventral pallium, accumulating in a ventrolateral wedge adjacent to the LGE in the nascent piriform cortex (Fig. $5 A$ ). The accumulation of $\mathrm{GFP}^{+}$ 
cells in a wedge shape in the piriform cortex closely mimicked the spatial pattern of $\mathrm{Tbr}^{+}$and $\operatorname{Trp} 73^{+}$cells observed above (Fig. $2 E, I)$. A similar ventrolateral stream of $\mathrm{GFP}^{+}$cells was also observed in Neurog $1^{-1-}$ mutants carrying one copy of the Neurog $2^{G F P \mathrm{KI}}$ allele, in Neurog $2^{\text {GFP KI/KI }}$ single mutants, and in Neurog $1^{-1-}$;Neurog $2^{\text {GFP KI/KI }}$ double mutants (Fig. 5B-D). Thus, the tangential migration of neurons derived from the ventral pallium into the piriform cortex is not grossly perturbed by the loss of Neurog1 and Neurog2. However, immunostaining with antiactivated caspase 3 revealed that there is elevated levels of apoptosis in the Neurog $2^{-1-}$ and Neurog $1 / 2^{-1-}$ ventral pallium at E12.5, after CR cell production has ended and the genesis of piriform cortical neurons has begun (Fig. $5 E-H$ ). To test whether cells with a piriform cortex identity were selectively lost in $\mathrm{Neu}$ $\operatorname{rog} 2^{-1-}$ and Neurog $1 / 2^{-1-}$ cortices, we examined the expression of $\operatorname{Lh} x 2$, a cortical selector gene that regulates a key decision between making neocortical versus piriform cortical structures (Chou et al., 2009). In E12.5 wild-type and Neurog $1^{-1-}$ cortices (Fig. $5 I, J$ ), a stream of $L h \times 2^{+}$cells emanated ventrally from the ventral pallium, marking the presumptive piriform cortex. In contrast, the $L h \times 2^{+}$presumptive piriform cortical neurons were disorganized in Neurog $2^{-1-}$ embryos and, strikingly, were lost in Neurog $1 / 2^{-1-}$ cortices (Fig. $5 K, L$ ).

To further assess piriform cortex development in E12.5 Neurog1 and Neurog2 single and double mutants, we monitored canonical Wnt signaling, which specifies a dorsal telencephalic cell fate (Gunhaga et al., 2003; Hirabayashi et al., 2004; Israsena et al., 2004; Backman et al., 2005; Machon et al., 2005; Watanabe et al., 2005). Wnt7b, which can initiate canonical signaling (Wang et al., 2005), was expressed in neurons migrating into the outer layers of the developing piriform cortex in E12.5 wild-type, Neurog $1^{-1-}$, and Neurog $2^{-1-}$ embryos (Fig. $5 M-P$ ). In contrast, Wnt7b expression was strikingly absent in the presumptive Neurog $1 / 2^{-/-}$ piriform cortex, although transcripts were still detected in the dorsal LGE (Fig. 5P). To further test whether canonical Wnt signaling was indeed disrupted, we monitored $\beta$-galactosidase activity in a transgenic line carrying a lef/tcf-lac $Z$ reporter (Mohamed et al., 2004). In E12.5 wild-type, Neurog1 ${ }^{-/-}$, and Neu$\operatorname{rog} 2^{-1-}$ embryos, lef/tcf-lacZ reporter activity was detected throughout the wedge of cells corresponding to the presumptive piriform cortex (Fig. 5Q-T). In contrast, the presumptive piriform cortex in E12.5 Neurog1/2 ${ }^{-1-}$ embryos was devoid of lef/ $t c f$-lac $Z$ reporter activity, indicating that canonical Wnt signaling was strongly reduced in the Neurog $1 / 2^{-/-}$piriform cortex (Fig. $5 T$ ). Finally, to test whether loss of a dorsal telencephalic identity was due to a transition to a ventral fate, we examined the expression of $D l x 1$. $D l x 1$ was ectopically expressed throughout the Neurog1/ $2^{-1-}$ piriform cortex (Fig. $5 U-X$ ), as previously shown in adjacent neocortical territories (Fode et al., 2000; Schuurmans et al., 2004).

Thus, the loss of both Neurog1 and Neurog2 does not prevent the migration of neurons derived from the ventral pallium into the presumptive piriform cortex, but rather results in a ventralization of these cells, which may contribute to their subsequent death.

\section{Lamination and cell fate specification defects in Neurog1/2 ${ }^{-1-}$ piriform cortex}

To further characterize defects in piriform cortex development in Neurog $1 / 2^{-1-}$ embryos, we first examined histological sections at E18.5, when neurogenesis and lamination are essentially complete. In E18.5 wild-type, Neurog1 ${ }^{-/-}$, and Neurog $2^{-/-}$brains, the transition from a six-layered neocortex to three-layered piriform cortex was evident as a medial inflection and narrowing of the densely stained neuronal layers (Fig. 6A-C). In contrast, in E18.5 Neurog1/
$2^{-1-}$ brains, the presumptive piriform cortex was thinner, hypocellular, and lacked densely stained neuronal layers (Fig. 6D).

To examine the basis of these histological defects, we used markers to label the different layers of the piriform cortex. In E15.5 wildtype, Neurog $1^{-1-}$, and Neurog $2^{-1-}$ embryos, Tbr1, which marks neocortical and piriform cortical neurons (Hevner et al., 2001), was expressed in all three layers of the piriform cortex (Fig. $6 E-G$ ). In contrast, many fewer neurons expressed Tbr1 in the E15.5 Neurog1/ $2^{-1-}$ piriform cortex (Fig. $6 H$ ), which is consistent with a similar reduction observed at E12.5 (Fig. $2 H$ ). Similarly, the expression of Ctip2, which was expressed in layer II of the E15.5 wild-type, Neu$\operatorname{rog} 1^{-1-}$, and Neurog $2^{-1-}$ piriform cortex, as well as Id2, which was expressed in layers II and III, were both strongly reduced in the Neurog $1 / 2^{-1-}$ piriform cortex (Fig. $6 I-P$ ). The loss of piriform cortex marker expression in Neurog $1 / 2^{-1-}$ embryos was not due to a transformation from a piriform to neocortical identity, as Fezf1 and Tle4, which mark upper and deep layer neocortical neurons, respectively, and which are not expressed in the piriform cortex, were not ectopically expressed in the presumptive piriform cortex of Neurog1/ $2^{-1-}$ embryos (data not shown).

While the piriform cortex has a ventral location, it has a dorsal origin, arising from lateral and ventral pallial progenitors. We thus reasoned that the loss of "dorsal" (cortical)-specific marker expression in the Neurog $1 / 2^{-/-}$piriform cortex could be due to a dorsal-to-ventral fate transition, resulting in the generation of ectopic interneurons, as previously shown in Neurog $2^{-1-}$ and Neurog1/2 ${ }^{-1-}$ neocortices (Fode et al., 2000; Schuurmans et al., 2004) and OBs (Shaker et al., 2012). We thus examined the expression of Etv1 and Pax6, which label dopaminergic periglomerular interneurons in the OB (Stenman et al., 2003; Kohwi et al., 2005; Saino-Saito et al., 2007), and Dlx1, which labels GABAergic interneurons in both the cortex and $\mathrm{OB}$ (Anderson et al., 1997; Long et al., 2007). All three interneuron markers were ectopically expressed in E15.5 Neurog $2^{-1-}$ and Neurog1/2 ${ }^{-1-}$ piriform cortices, whereas only scattered piriform cortex interneurons expressed these markers in E15.5 wild-type and Neurog $1^{-1-}$ embryos (Fig. 6Q-Z,A',B'). However, neuronal misspecification was much more severe in the double-mutant piriform cortex, with ectopic Etv1 and Pax6 expression detected in all three layers (Fig. 6T,B'), while ectopic Dlx1 expression was restricted to deep layer III (Fig. 6X).

Together, these results suggest that the Neurog1/2 ${ }^{-1-}$ piriform cortex is comprised of neurons with aberrant molecular identities. Strikingly, the "ventralized" neurons have a similar molecular signature as OB interneurons, which are derived from the dorsal LGE, a subpallial progenitor domain that lies immediately adjacent to the ventral pallium (Vergaño-Vera et al., 2006; Flames and Hobert, 2009).

\section{LOT formation is perturbed in the Neurog $1 / 2^{-/-}$double- mutant piriform cortex}

The piriform cortex is part of a three-part neural network that also includes the $\mathrm{OE}$ and $\mathrm{OB}$, which together mediate the primary sense of olfaction. We previously showed that Neurog $1 / 2^{-I-}$ double mutants only form a remnant of an OB-like structure (OBLS) in an aberrant ventral position (Shaker et al., 2012). Nevertheless, despite this abnormal architecture, some glutamatergic mitral cells, which are the output neurons of the OB that target the piriform cortex, differentiate in the Neurog1/2-1- OBLS (Shaker et al., 2012). We therefore questioned whether Neurog $1 / 2^{-1-}$ mitral cell axons are capable of forming a LOT that innervates the piriform cortex.

To trace LOT axons, a DiI crystal was inserted into the OB of E18.5 wild-type and Neurog1 and Neurog2 single-mutant and 

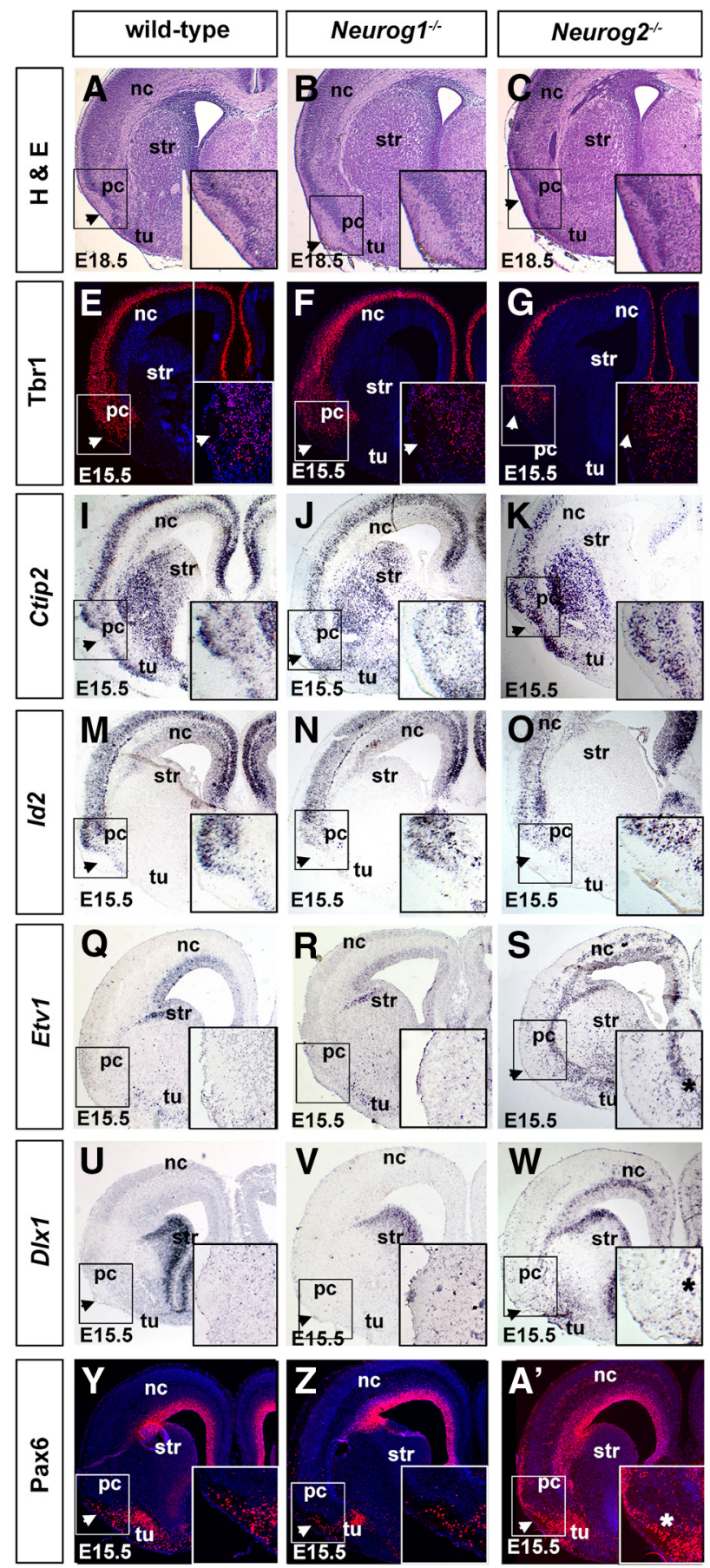

Figure 6. Defects in lamination and cell fate specification in the Neurog $1 / 2^{-1-}$ piriform cortex. $A-D$, Hematoxylin and eosin staining of E18.5 wild-type $(\boldsymbol{A})$, Neurog $1^{-1-}(\boldsymbol{B})$, Neurog $2^{-1-}(\boldsymbol{C})$, and Neurog $1 / 2^{-1-}(\boldsymbol{D})$ cortices. Arrowheads in $A-C$ mark site of LOT formation. $\boldsymbol{E}-\mathbf{Z}, \boldsymbol{A}^{\prime}, \boldsymbol{B}^{\prime}$, Expression of Tbr1 (E-H), Ctip2 (I-L), Id2 (M-P), Etv1 (Q-T), Dlx1 (U-X), and Pax6 $\left(\boldsymbol{Y}, \mathbf{Z}, \boldsymbol{A}^{\prime}, \boldsymbol{B}\right)$ in E15.5 wild-type

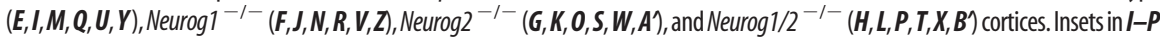
are high-magnification images of the piriform cortex. Asterisks in $\boldsymbol{L}$ and $\boldsymbol{P}$ show reduced expression of Ctip2 and $/ d 2$ in the Neurog $1 / 2^{-1}$ piriform cortex. Arrowheads in $\boldsymbol{S}, \boldsymbol{I}, \boldsymbol{W}, \boldsymbol{X}, \boldsymbol{A}^{\prime}$, and $\boldsymbol{B}^{\prime}$ mark the ectopic expression of Etv1, Dlx 1 , and Pax6 in Neurog $2^{-1-}$ and Neurog $1 / 2^{-1-}$ piriform cortices. nc, Neocortex; $p c$, piriform cortex; str, striatum; tu, olfactory tubercle.

double-mutant embryos (Fig. $7 A-D$ ). In E18.5 wild-type embryos, DiI-labeled LOT axons formed a narrow axon bundle that extended along the lateral surface of the telencephalon before turning in a ventral direction to innervate the piriform cortex (Fig. 7A). DiI crystals inserted into the Neurog $1^{-1-}$ OB also anterogradely labeled the LOT (Fig. 7B), even though the Neurog $1^{-/-}$OB is smaller and abnormally laminated (Shaker et al., 2012). Likewise, Neu-
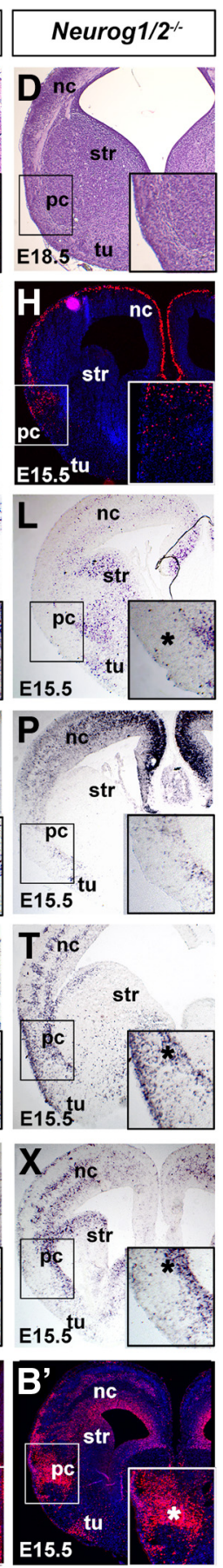

$\operatorname{rog} 2^{-1-}$ mitral cells, which differentiate normally (Shaker et al., 2012), also formed a LOT (Fig. 7C). In contrast, in E18.5 Neu$\operatorname{rog} 1 / 2^{-1-}$ brains, DiI crystals placed in the rostroventral telencephalon did not label a distinct LOT, suggesting that the ectopically localized mitral cells in the Neurog $1 / 2^{-1-}$ OBLS failed to extend axons to innervate the piriform cortex (Fig. 7D).

To confirm that LOT formation did not occur in Neurog $1 / 2^{-1-}$ embryos, we examined calretinin expression. Calretinin immunolabeling was detected in mitral cell axon bundles innervating the piriform cortex in E15.5 wild-type, $\mathrm{Neu}$ rog $1^{-1-}$, and Neurog $2^{-1-}$ brains (Fig. 7E$\left.H^{\prime}\right)$. In contrast, a calretinin ${ }^{+}$axonal bundle was not observed in the presumptive piriform cortex in Neurog $1 / 2^{-1-}$ mutants (Fig. $7 H, H^{\prime}$ ). To further examine LOT formation, we examined embryos carrying a Neurog $2^{G F P K I}$ allele, which serves as a short-term lineage trace of glutamatergic projection neurons in both the neocortex and OB (Britz et al., 2006; Shaker et al., 2012). A distinct $\mathrm{GFP}^{+}$LOT was observed in the piriform cortex of

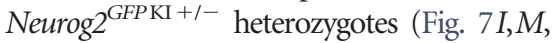
Q), as well as in Neurog1 ${ }^{-1-}$ mutants carrying one copy of the Neurog $2^{G F P K I}$ allele (Fig. $7 J, N, R)$ and Neurog $2^{G F P \mathrm{KI} / \mathrm{KI}}$ single mutants (Fig. $7 K, O, S$ ). In contrast, a $\mathrm{GFP}^{+}$ LOT was not evident in the Neurog $1^{-1-}$; Neurog $2^{G F P K I / K I}$ piriform cortex (Fig. $7 L, P, T)$. Notably, the LOT, which is comprised of mitral cell axons, was also distinguishable in wild-type, Neurog $1^{-1-}$, and Neurog $2^{-1-}$ piriform cortex by the absence of MAP2 expression, which is a dendritic marker (Fig. 7M-O), whereas a MAP2-free zone was not observed in the presumptive Neurog $1 / 2^{-1-}$ piriform cortex (Fig. $7 P$ ). Thus, although some mitral cells differentiate in the Neurog $1 / 2^{-1-}$ OBLS, they fail to innervate the piriform cortex.

\section{Defects in the differentiation of lot 1} guidepost neurons in the Neurog1/2 ${ }^{-1-}$ piriform cortex

LOT formation depends on lot guidepost cells, which have a dorsal pallial origin (Sato et al., 1998; Tomioka et al., 2000). We speculated that the failure of LOT formation in the Neurog $1 / 2^{-1-}$ piriform cortex could be due to defects in the differentiation of lot cells, which could be derived from a Neurog2-lineage. To monitor lot cell formation, we took advantage of two markers: a lot-cell-specific monoclonal antibody called lot1 (Sato et al., 1998), which recently was shown to recognize metabotropic glutamate receptor subtype-1 (mGluR1), and an mGluR1 riboprobe (Hirata et al., 2012). To first determine whether lot cells were derived from the Neurog2 lineage, 
we performed lot1 immunolabeling on embryos carrying a Neurog $2^{G F P \mathrm{KI}}$ allele. In

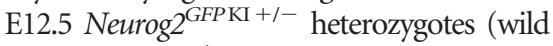
type), Neurog $1^{-1-}$ mutants carrying one copy of the Neurog $2^{\text {GFP KI }}$ allele, Neurog $2^{\text {GFP KI/KI }}$ single mutants, and Neurog2 ${ }^{\text {GFP KI/KI}}$; Neurog $1^{-1-}$ double mutants, lot1 and GFP were coexpressed (Fig. 8A-C). However, in Neurog $1 / 2^{-/-}$embryos, many fewer lot $1^{+}$cells migrated into the presumptive piriform cortex compared with all other genotypes (Fig. $8 D$ ). Similarly, $m G l u R 1$ was expressed in the presumptive piriform cortex in E12.5 wild-type, Neurog1 $1^{-1-}$, and Neurog $2^{-1-}$ piriform cortex, whereas many fewer $m G l u R 1^{+}$lot cells were detected in Neurog1/ $2^{-1-}$ embryos (Fig. 8E-H). Expression of lot1 persisted in the piriform cortex at E15.5, with notable defects only observed in $\mathrm{Neu}$ $\operatorname{rog} 1 / 2^{-/-}$piriform cortex (Fig. $8 I-L^{\prime}$ ). The differentiation of lot cells is thus strikingly reduced in Neurog $1 / 2^{-1-}$ embryos.

We were struck by the similarities in the E12.5 expression profiles of lot1 (Fig. $8 A-D$ ) and $\operatorname{Trp} 73$ (Fig. 2I-L), which labels a subset of CR cells (Meyer et al., 2002, 2004). Given their similarities, we speculated that lot guidepost cells could be a subpopulation of CR neurons. While previous studies have suggested that there is limited overlap in the expression of lot 1 and Reelin (Sato et al., 1998), in our studies, which were conducted on sections instead of in whole-mount, we found that a subset of E12.5 lot ${ }^{+}$cells indeed coexpressed Reelin (Fig. $8 M, N, N^{\prime}$ ) and Trp73, the full-length Trp73 isoform (Fig. $\left.80, P, P^{\prime}\right)$. Moreover, quantitation of coexpression rates revealed that the high lot $1^{+}$cells that surround the LOT frequently coexpressed Reelin (94.5 $\pm 0.8 \%$, $n=3,697$ cells) and Trp73 (96.0 $\pm 1.2 \%$, $n=3,1068$ cells), while the lowerexpressing $\operatorname{lot} 1^{+}$cells that are farther away from the LOT displayed reduced levels of Reelin (39.6 $\pm 4.0 \%, n=3,2228$ cells) and $\operatorname{Trp} 73(43.5 \pm 4.2 \%, n=3$, 2218 cells) coexpression (Fig. 8Q).

We thus conclude that lot guidepost cells are a subset of CR neurons, revealing that these cells have a pallial origin, and depend on both Neurog1 and Neurog2 for their differentiation (Fig. 8R,S).

\section{$\operatorname{Trp} 73$ is required for LOT formation and lot cell positioning}

We reasoned that if lot cells were indeed a subpopulation of Reelin ${ }^{+} / \operatorname{Trp} 73^{+} \mathrm{CR}$ neurons, that the mutation of Reelin and/or Trp73 could in turn influence lot cell formation and/or function. Indeed, Reelin is required for cellular orientation of neocortical layer VI neurons (O'Dell et

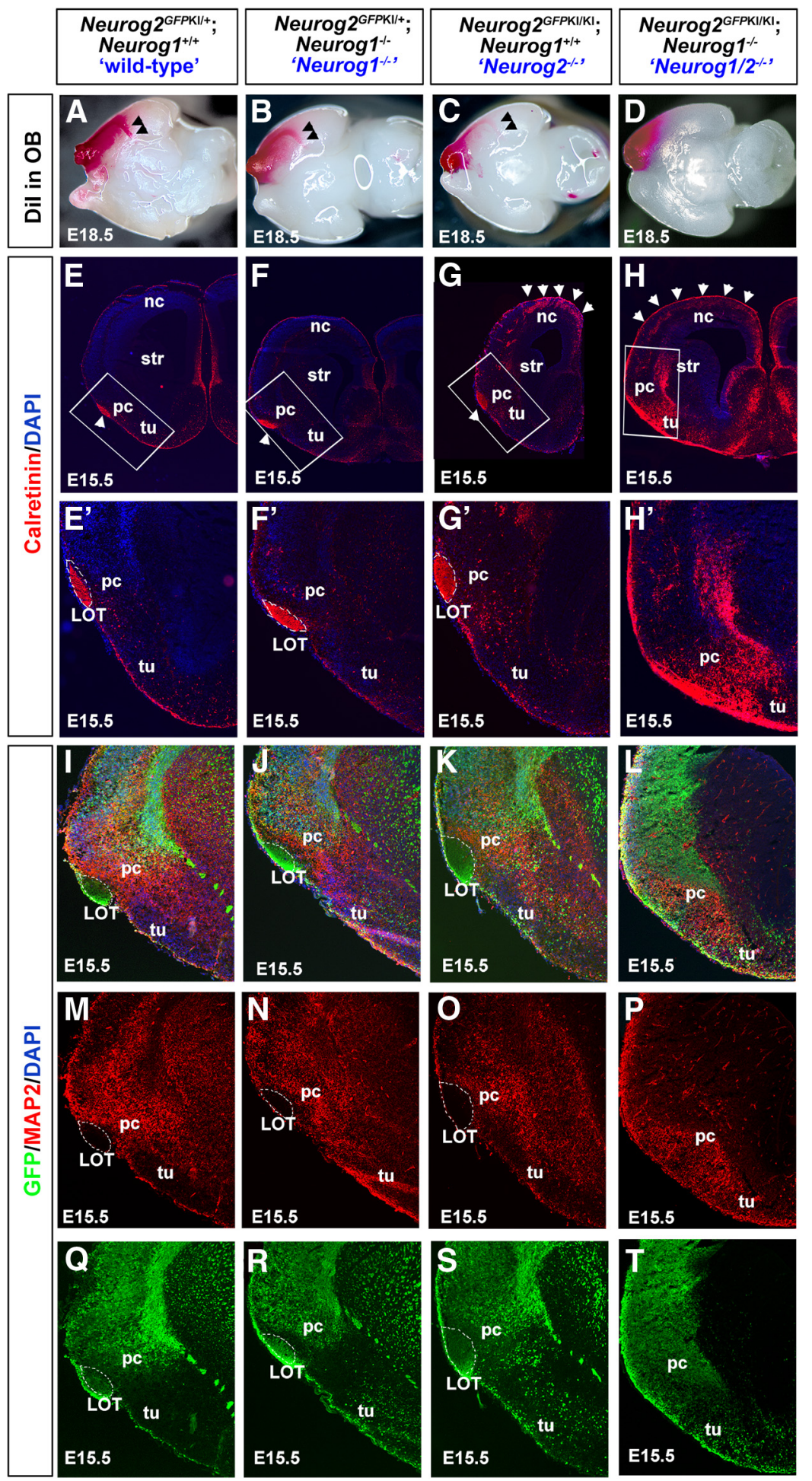

Figure 7. LOT formation is perturbed in the Neurog $1 / 2^{-/-}$piriform cortex. A-D, LOT axons were traced by inserting a Dil crystal into E18.5 wild-type $(\boldsymbol{A})$, Neurog $1^{-1-}(\boldsymbol{B})$, Neurog $2^{-1-}\left(\boldsymbol{C}\right.$, and Neurog $1 / 2^{-1-}(\boldsymbol{D})$ OBs. Arrowheads mark the ventromedial turn of the forming LOT, which fails to form in Neurog $1 / 2^{-1-}$ embryos. $E-H^{\prime}$, Labeling of OB mitral cell axons in the LOT with anti-calretinin in E15.5 wild-type $\left(\boldsymbol{E}, \boldsymbol{E}^{\prime}\right)$, Neurog $1^{-1-}(\boldsymbol{F}, \boldsymbol{F})$, Neurog2 ${ }^{-1-}\left(\boldsymbol{G}, \boldsymbol{G}^{\prime}\right)$, and Neurog1/2 $2^{-l-}(\boldsymbol{H}, \boldsymbol{H})$ piriform cortices. Blue is a DAPI counterstain. $\boldsymbol{E}^{\prime}-\boldsymbol{H}^{\prime}$ are higher-magnification images of boxed areas in $\boldsymbol{E}-\boldsymbol{H}$. Arrowheads in $\boldsymbol{G}$ and $\boldsymbol{H}$ mark supernumerary calretinin ${ }^{+}$interneurons in Neurog $2^{-I-}$ and Neurog $1 / 2^{-I-}$ neocortices, respectively. $I-I$, Expression of GFP (green) and MAP2 (red) in E15.5 Neurog $2^{G F P \mathrm{KI}+/-}$ heterozygotes ("wild-type"; I, M, Q), Neurog $1^{-/-}$mutants carrying one copy of the Neurog $2^{G F P K I}$ allele $(\boldsymbol{J}, \boldsymbol{N}, \boldsymbol{R})$, Neurog $2^{G F P \mathrm{KI} / \mathrm{KI}}$ mutants $(\boldsymbol{K}, \mathbf{O}, \mathbf{S})$, and Neurog $1^{-1-} ;$ Neurog $2^{G F P \mathrm{KI} / \mathrm{Kl} \mathrm{d}}$ double mutants (Neurog1/ $\left.2^{-I-} ; \boldsymbol{L}, \boldsymbol{P}, \boldsymbol{T}\right)$. Blue is a DAPI counterstain. The dotted white line outlines the LOT. nc, Neocortex; pc, piriform cortex; str, striatum; tu, olfactory tubercle. 


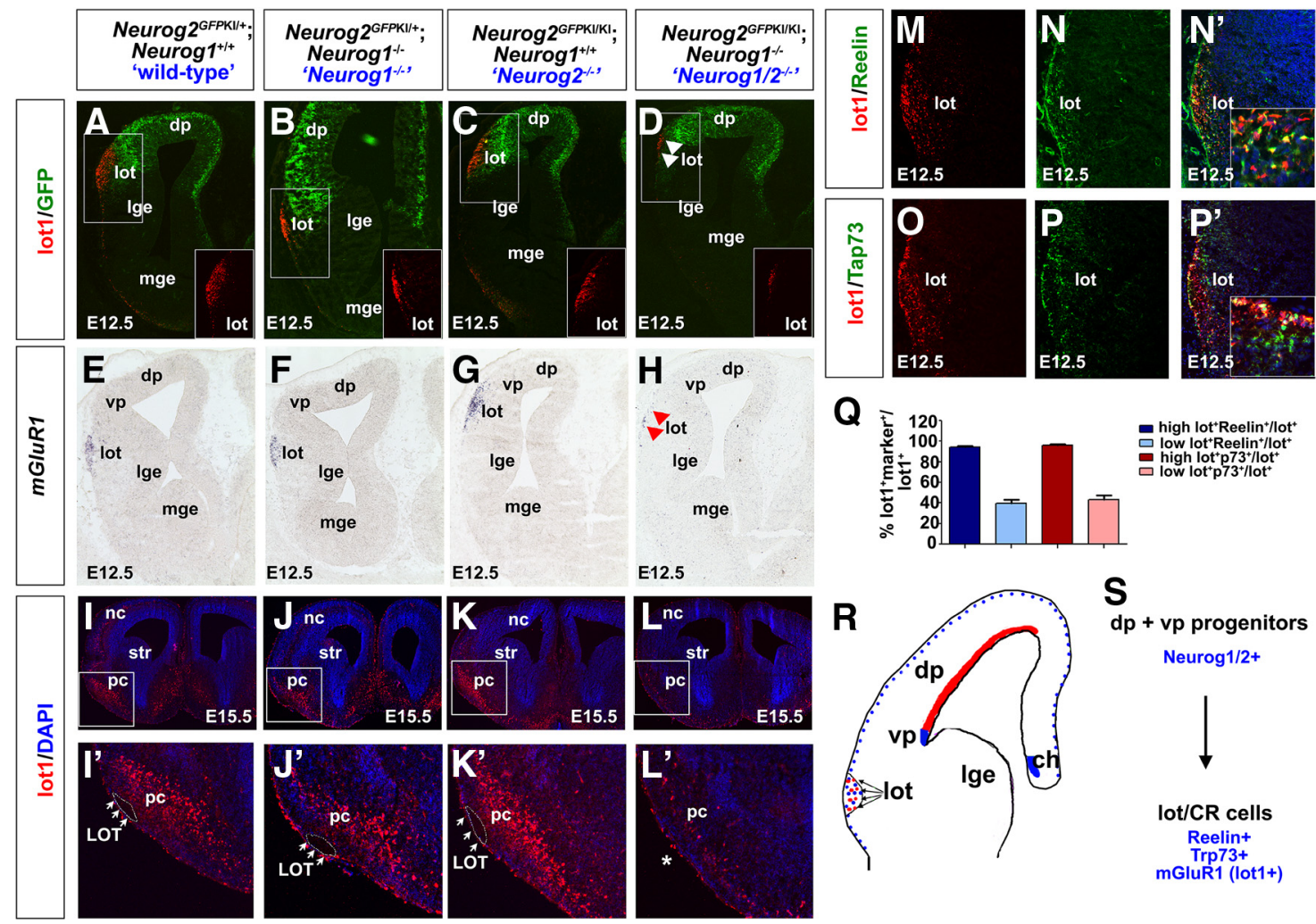

Figure 8. Lot cells, which are reduced in number in the Neurog $1 / 2^{-/-}$piriform cortex, are a subpopulation of $C R$ cells. $\boldsymbol{A}-\boldsymbol{H}$, Labeling of E12.5 telencephalons from Neurog $2^{G F P \mathrm{KI}+/-}$ heterozygotes ("wild-type"; $\boldsymbol{A}, \boldsymbol{E})$, Neurog $1^{-I-}$ mutants carrying one copy of the Neurog $2^{G F P \mathrm{KI}}$ allele $(\boldsymbol{B}, \boldsymbol{F})$, Neurog $2^{G \mathrm{FP} \mathrm{KI} / \mathrm{Kl}}$ mutants $(\boldsymbol{C}, \boldsymbol{G})$, and Neurog $1^{-I-} ;$ Neurog $2^{G F P \mathrm{KI} / \mathrm{Kl}}$ double mutants (Neurog1/2 $\left.{ }^{-1-} ; \boldsymbol{D}, \boldsymbol{H}\right)$ with anti-lot1 $(\boldsymbol{A}-\boldsymbol{D}$, red), anti-GFP $(\boldsymbol{A}-\boldsymbol{D}$, green), and a $\mathrm{mGluR1}$ riboprobe $(\boldsymbol{E}-\boldsymbol{H})$. Insets in $\boldsymbol{A}-\boldsymbol{D}$ are lot1 immunostaining of the lot. Arrows in $\boldsymbol{D}$ and $\boldsymbol{H}$ mark a loss of lot cells

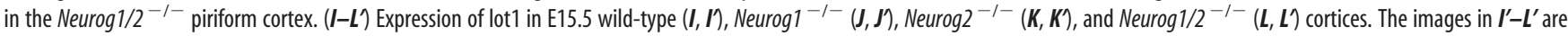
high-magnification images of the boxed areas in $\boldsymbol{I}-\mathbf{L} . \mathbf{M}-\boldsymbol{P}$, Coexpression of lot1 $\left(\boldsymbol{M}, \boldsymbol{N}^{\prime}\right.$, red) and Reelin $\left(\boldsymbol{N}, \boldsymbol{N}^{\prime}\right.$, green), and of lot1 $\left(\mathbf{0}, \boldsymbol{P}^{\prime}\right.$, red) and $\operatorname{Trp} 73(\boldsymbol{P}, \boldsymbol{P})$ in the lot. Blue is DAPI counterstain in $\boldsymbol{N}^{\prime}$ and $\boldsymbol{P}^{\prime}$. Insets in $\boldsymbol{N}^{\prime}$ and $\boldsymbol{P}^{\prime}$ are higher-magnification images of the lot. $\boldsymbol{Q}$, Quantitation of the coexpression of lot1 with Reelin and Trp73. Cells that expressed high levels of lot1, which surround the LOT, were counted separately from those displaced from the lot (high and low lot ${ }^{+}$cells, respectively). $\boldsymbol{R}$, Schematic representation of E12.5 telencephalon, depicting the suggested dorsal pallial source of lot cells (red), and the cortical hem and ventral pallium as the sites of (R cell genesis (blue). S, Summary of our findings, demonstrating that Neurog 1 and Neurog 2 are coexpressed in dorsal and ventral pallial progenitors, which give rise to lot cells, a subset of Reelin ${ }^{+} / \mathrm{Trp} 73^{+} \mathrm{CR}$ cells. ch, Cortical hem; dp, dorsal pallium; Ige, lateral ganglionic eminence; lot, lot guidepost cells; vp, ventral pallium.

al., 2012), while Trp73 is required for CR cell genesis (Meyer et al., 2004). Notably, Trp73 has two transcriptional start sites, and it is only the larger TAp73 protein, which is generated via transcription from an upstream P1 promoter, that is a functional transcription factor (Conforti et al., 2012). Moreover, the TAp73 isoform regulates the expression of Hey2, a repressor of bHLH proteins, such as Neurog1 and Neurog2 (Sakamoto et al., 2003; Fujitani et al., 2010). Thus, to test whether genes involved in CR genesis and/or function also influenced lot formation, we analyzed E15.5 Reeler, Trp $73^{-1-}\left(p 73^{-1-}\right)$, and TAp73 $3^{-1-}$ cortices.

We first examined whether $\mathrm{CR}$ cell production was affected in these mutants. Interestingly, while the expression of Trp73 in neocortical and cortical CR cells appeared normal in E15.5 Reeler mutants (Fig. 9A,B), the expression of Reelin was strikingly reduced in the $p 73^{-1-}$ and TAp $73^{-1-}$ piriform cortical and neocortical marginal zones (Fig. $9 C-E$ ), which is consistent with previous studies (Meyer et al., 2002, 2004). Thus, if CR cells remain in $p 73^{-1-}$ and TAp $73^{-1-}$ cortices, they have an abnormal molecular identity.

Next we examined whether LOT formation, which depends on lot cells (Sato et al., 1998), was disrupted in the absence of Reelin and $p 73$. Strikingly, calretinin immunolabeling marked a larger and less clearly defined LOT in both $p 73^{-1-}$ and TAp $73^{-1-}$ piriform cortices (Fig. 9H-J,M-O), whereas LOT formation was normal in Reeler mutants (Fig. $9 F, G, K, L, O$ ). In ad- dition, the borders of the LOT were not well circumscribed in $p 73^{-1-}$ and $T A p 73^{-1-}$ piriform cortices. Instead, DAPI ${ }^{+}$cells were found within the interior of the LOT (Fig. $9 K-N, T$ ). Furthermore, immunostaining with lot 1 revealed that lot guidepost cells were in some instances aberrantly localized within the LOT in $p 73^{-1-}$ and $T A p 73^{-1-}$ mutants (Fig. 9M,N,R-T), whereas lot $1^{+}$cells were rarely observed in the LOT in wild-type or Reeler mutant cortices (Fig. $9 K, L, P, Q, T$ ).

Thus, not only is Trp73 expressed in lot cells, which are a subpopulation of CR neurons, but $p 73$ is also required for the proper organization of lot cells, and for the subsequent innervation of the piriform cortex by LOT axons.

\section{Discussion}

The cerebral cortex is comprised of the archicortex, neocortex, and piriform cortex, each derived from distinct pallial progenitor domains during development. Within each pallial territory, progenitor cells undergo temporal identity transitions, so that the diverse neuronal populations that make up each cortical structure are generated at their correct times and in proper numbers. Here we demonstrate that the proneural genes Neurogl and Neurog2 form a regulatory loop to temporally control successive cell fate decisions in the ventral pallium. At early stages, either $\mathrm{Neu}$ rog1 or Neurog2 are required to specify a CR cell identity. In addition, Neurog1 has an added early role-preventing preco- 

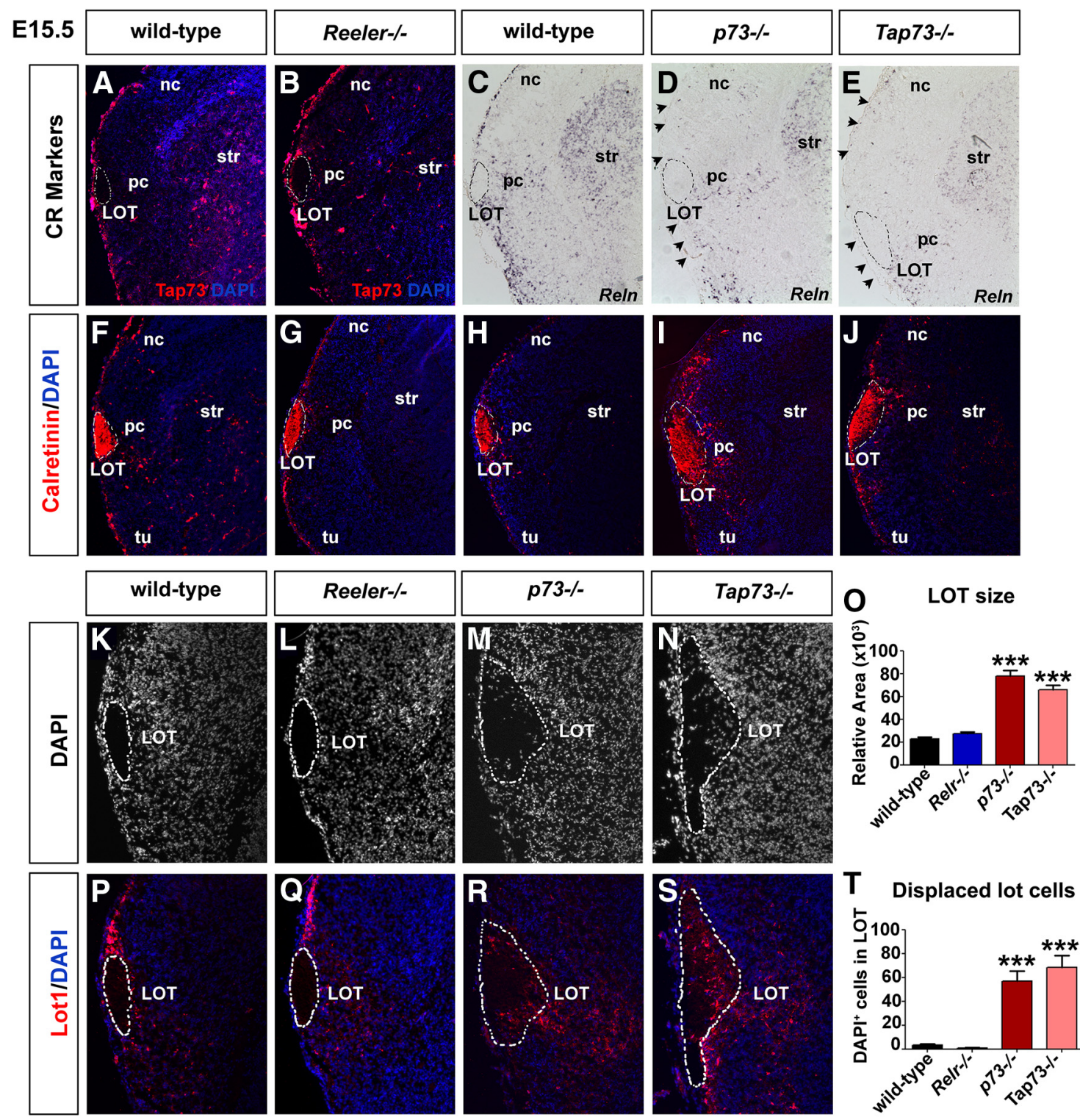

Figure 9. Defects in LOT formation and lot cell positioning in p73 and TAp73 mutants. $\boldsymbol{A}-\boldsymbol{J}$, Expression of Trp73 $(\boldsymbol{A}, \boldsymbol{B}), \operatorname{Reelin}(\boldsymbol{C}, \boldsymbol{D})$, and calretinin $(\boldsymbol{F}-\boldsymbol{J})$ in E15.5 wild-type $(\boldsymbol{A}, \boldsymbol{C}, \boldsymbol{F}, \boldsymbol{H})$, Reeler ${ }^{-/-}$ $(\boldsymbol{B}, \boldsymbol{G}), p 73^{-1-}(\boldsymbol{D}, \boldsymbol{I})$, and $\operatorname{TAp}^{-1-}(\boldsymbol{E}, \boldsymbol{J})$ cortices. $\boldsymbol{K}-\boldsymbol{T}$, DAPI staining $\left(\boldsymbol{K}-\boldsymbol{N} ; \boldsymbol{P}-\boldsymbol{S}\right.$, blue counterstain) and lot1 immunolabeling $\left(\boldsymbol{P}-\boldsymbol{S}\right.$, red label) of E15.5 wild-type $(\boldsymbol{K}, \boldsymbol{P})$, Reeler ${ }^{-1-}(\boldsymbol{L}, \boldsymbol{Q})$, $p 73^{-1-}(\boldsymbol{M}, \boldsymbol{R})$, and $\operatorname{TAp}^{-1-}(\boldsymbol{N}, \mathbf{S})$ piriform cortices. The LOT is outlined by a dashed white line, following the contours of the area of tight cellular packing. Quantitation of relative area measurements of the LOT in each genotype (0). Quantitation of the number of DAPI ${ }^{+}$cells displaced within the LOT $(\boldsymbol{T})$. nc, Neocortex; $p c$, piriform cortex; str, striatum; tu, olfactory tubercle.

cious neurogenesis by limiting Neurog2's ability to specify a CR cell fate. Hence, in the absence of Neurog1, more CR cells are generated. Furthermore, we reveal that Neurog1 and Neurog2 are required to specify the identity of a subset of CR neurons in the piriform cortex: lot guidepost cells. Accordingly, we demonstrate that Trp73, which is expressed in CR cells (Meyer et al., 2002, 2004) and lot cells (this study), is required for normal LOT axon innervation of the piriform cortex. Finally, we demonstrate that at later developmental stages, Neurog1 and Neurog2 change their fate specification properties in the ventral pallium, guiding the differentiation of layer II/III piriform cortical neurons.

Neurog1 and Neurog2 have overlapping and nonoverlapping functions in CR progenitors

Neurog1 and Neurog2 are expressed in CR cell lineages derived from all three progenitor domains (this study; Dixit et al., 2011b), including the rostrobulbar area/pallial septum, cortical hem/cho- roid plexus, and ventral pallium (Takiguchi-Hayashi et al., 2004; Bielle et al., 2005; Yoshida et al., 2006; Zhao et al., 2006; GarcíaMoreno et al., 2007; Imayoshi et al., 2008). Neurog2-derived CR cells are widespread, populating the piriform cortex, neocortex, and hippocampus (this study; Dixit et al., 2011b). It is thus not surprising that we observed a global reduction in CR cell numbers in all cortical domains in Neurog $1 / 2^{-1-}$ embryos. What was unexpected was the increase in CR numbers in Neurog ${ }^{-1-}$ embryos, and the ability of Neurog1 to limit Neurog2's ability to specify a Reelin ${ }^{+} \mathrm{CR}$ cell identity in gain-of-function assays. We suggest that the transition from generating $\mathrm{CR}$ neurons to deeplayer cortical neurons in the neocortex and piriform cortex depends on Neurog1's ability to curtail Neurog2's early proneural and cell fate specification properties. While future studies are required to address mechanism, it may be that Neurog1-Neurog2 heterodimers might have a reduced capacity to transactivate target genes compared with Neurog2-Neurog2 homodimers. In- 
deed, in a previous study we revealed that Neurog2's proneural activities are temporally regulated by their dimerization partner, and that Neurog2-Neurog2 homodimers are more active than Neurog2-E47 heterodimers (Li et al., 2012).

Unexpected was the striking and specific loss of $\operatorname{Trp} 73^{+} \mathrm{CR}$ cells in a V-shaped wedge in the Neurog $1 / 2^{-1-}$ piriform cortex. $\operatorname{Trp} 73^{+}$CR cells are thought to arise from the cortical hem and pallial septum (Meyer et al., 2002, 2004; Hanashima et al., 2007). However, in a Dbx1-lineage trace (Bielle et al., 2005), which labels CR cells derived from the ventral pallium and pallial septum, lac $Z^{+}$cells accumulate in the piriform cortex in a pattern that closely resembles the wedge-shaped distribution of $\operatorname{Trp} 73^{+}$cells (this study). While it has been suggested that pallial septumderived CR cells in the Dbx1 lineage are $\operatorname{Trp} 73^{+}$(Griveau et al., 2010), our data support the idea that some of these $\operatorname{Trp} 73^{+} \mathrm{CR}$ cells may also be derived from the ventral pallium. Interestingly, the pattern of $\operatorname{Tr} p 73$ expression in the wild-type piriform cortex is the same as lot $1 / m G l u R 1$, which label lot guidepost cells (Sato et al., 1998; Hirata et al., 2012). Moreover, lot1/mGluR1 expression was strikingly reduced in the Neurog $1 / 2^{-1-}$ piriform cortex. These data, combined with our coexpression data, are good evidence that lot guidepost cells are a subpopulation of CR cells that depend on Neurog1 and Neurog2 for their differentiation.

\section{Neurog1 and Neurog2 specify the identities of piriform cortical neurons}

Recent studies have suggested that CR cells influence regional identities and boundary formation in the underlying cortical neuroepithelium (Griveau et al., 2010). Specifically, the loss of $D b x 1$, which is expressed in CR progenitors in the ventral pallium and pallial septum, alters the distribution of the remaining CR cells (Bielle et al., 2005), thereby shifting the regional borders that prefigure cortical areas (Griveau et al., 2010). Similar compensatory changes likely influence the distribution of remaining CR cells in Neurog $2^{-1-}$ and Neurog1/2 $2^{-1-}$ cortices. This raises the question of whether the patterning defects in Neurog $2^{-1-}$ and Neurog $1 / 2^{-1-}$ cortices are related in any way to CR cell changes. It is difficult to reach a definitive answer to this question, since the mis-specification of Neurog $2^{-1-}$ and Neurog $1 / 2^{-1-}$ cortical progenitors may instead be linked to a requirement to suppress expression of Ascl1, another proneural gene that specifies a ventral telencephalic phenotype (Fode et al., 2000; Schuurmans et al., 2004). Nevertheless, it is remarkable that the phenotype of the ectopic interneurons in Neurog $2^{-1-}$ and Neurog $1 / 2^{-1-}$ cortices most closely resemble $\mathrm{OB}$ interneurons (i.e., Etv ${ }^{+}, \mathrm{Pax}^{+}$, $D l \times 1^{+}$, calretinin ${ }^{+}$; Yun et al., 2001, 2003), an interneuron population that is normally derived from the dorsal LGE (Long et al., 2003, 2007; Stenman et al., 2003; Yun et al., 2003; Kohwi et al., 2005). Interestingly, the dorsal LGE is a subpallial progenitor domain that immediately abuts the ventral pallium (Yun et al., 2001). It is thus tempting to speculate that the mis-specification of Neurog $2^{-1-}$ and Neurog $1 / 2^{-1-}$ cortical territories may be due to a shift in the pallial-subpallial border, and that this shift may be related to alterations in the distribution and identity of CR cells. In contrast, the border between the neocortex and piriform cortex does not appear to be shifted in Neurog $1 / 2^{-1-}$ embryos, as the loss of piriform cortex markers does not correlate with an expansion of neocortical markers Fezf1 and Tle4. In this regard, Neurog $1 / 2^{-1-}$ mutants differ from Tbr1 mutants, which ectopically express neocortical markers in the piriform cortex (Hevner et al., 2001).

Based on marker expression (Hirata et al., 2002), as well as short-term lineage tracing using Neurog $2^{G F P K I}$ mice (this study) and long-term lineage tracing using Dbx1-cre ${ }^{\mathrm{KI}}$ mice (Bielle et al., 2005), neurons in the piriform cortex are generated from progenitor cells in the ventral pallium. Hypocellularity of the Neu$\operatorname{rog} 2^{-1-}$ and Neurog $1 / 2^{-1-}$ piriform cortices is likely related to increased apoptosis in the ventral pallium. Notably, in Pax6 mutants, neuronal mis-specification leads to elevated apoptosis due to altered expression of the neurotrophin receptors TrkB and p75NTR (Nikoletopoulou et al., 2007). Interestingly, Dbx1 expression, which marks the ventral pallium, is lost in Pax6 mutants (Yun et al., 2001), whereas in Neurog $2^{-1-}$ and Neurog1/2 $2^{-1-}$ cortices, $D b x 1$ expression is retained (this study). Moreover, TrkB expression persists in the Neurog $2^{-1-}$ and Neurog1/2 ${ }^{-1-}$ ventral pallium (data not shown), which undergoes massive cell death, suggesting that the expression of this neurotrophin receptor alone may not be sufficient to prevent apoptosis in misspecified pallial progenitors.

\section{CR cells function in axon guidance}

The piriform cortex is part of the olfactory system, which also includes the $\mathrm{OE}$ and $\mathrm{OB}$. While the $\mathrm{OE}, \mathrm{OB}$, and piriform cortex are separate functional entities, they develop as an interconnected unit (de Castro, 2009). Interestingly, Neurog1 and/or Neurog2 are expressed in progenitor cells for each of these components of the olfactory system, including the OE (Cau et al., 2002), OB (Winpenny et al., 2011; Shaker et al., 2012), and piriform cortex (this study). While the differentiation of olfactory sensory neurons is perturbed in Neurog $1^{-1-}$ single mutants, disruptions in $\mathrm{OB}$ (Shaker et al., 2012) and piriform cortex (this study) development are most severe in Neurog $1 / 2^{-1-}$ double mutants. Neurog $1 / 2^{-1-}$ embryos develop a hypocellular OBLS in an aberrant ventrolateral position (Shaker et al., 2012). However, even though some mitral cells differentiate in the Neurog1/2 ${ }^{-1-}$ OBLS (Shaker et al., 2012), we show here that these OB projection neurons fail to innervate the piriform cortex (i.e., form a LOT) due to the loss of lot guidepost cells (Sato et al., 1998). Notably, a similar OBLS phenotype is observed in $\mathrm{Pax6}^{-1-}$ (Hirata et al., 2002), Lhx2 $2^{-1-}$ (Saha et al., 2007), and Gli3 ${ }^{-1-}$ (Balmer and LaMantia, 2004) mutants, yet only $\mathrm{Pax6}^{-1-}$ mitral cells extend their axons out of the OB to form the LOT and innervate the piriform cortex (Hirata et al., 2002). In contrast, in Gli3 $^{-/-}$mutants, in which lot cells fail to migrate into the piriform cortex and instead accumulate in the neocortex (Tomioka et al., 2000; Balmer and LaMantia, 2004), and in $L h \times 2^{-1-}$ cortices, where lot cells fail to differentiate (Saha et al., 2007), LOT formation is perturbed. CR cells thus have multiple roles in building the architecture of the cortex: not only in patterning the cortical VZ (Griveau et al., 2010), but also in axonal guidance of olfactory tracts (this study).

Through these findings, we provide new insights into the control of temporal identity transitions and neuronal fate specification in the piriform cortex, a poorly understood brain region. Moreover, we identify a novel population of CR neurons (lot cells), and ascribe a new function to $\operatorname{Tr} p 73$, which is expressed in these lot/CR cells, in LOT formation.

\section{References}

Alam S, Zinyk D, Ma L, Schuurmans C (2005) Members of the Plag gene family are expressed in complementary and overlapping regions in the developing murine nervous system. Dev Dyn 234:772-782. CrossRef Medline

Alcántara S, Ruiz M, D’Arcangelo G, Ezan F, de Lecea L, Curran T, Sotelo C, Soriano E (1998) Regional and cellular patterns of reelin mRNA expression in the forebrain of the developing and adult mouse. J Neurosci 18: 7779-7799. Medline 
Anderson SA, Qiu M, Bulfone A, Eisenstat DD, Meneses J, Pedersen R, Rubenstein JL (1997) Mutations of the homeobox genes Dlx-1 and Dlx-2 disrupt the striatal subventricular zone and differentiation of late born striatal neurons. Neuron 19:27-37. CrossRef Medline

Assimacopoulos S, Grove EA, Ragsdale CW (2003) Identification of a Pax6dependent epidermal growth factor family signaling source at the lateral edge of the embryonic cerebral cortex. J Neurosci 23:6399-6403. Medline

Backman M, Machon O, Mygland L, van den Bout CJ, Zhong W, Taketo MM, Krauss S (2005) Effects of canonical Wnt signaling on dorso-ventral specification of the mouse telencephalon. Dev Biol 279:155-168. CrossRef Medline

Balmer CW, LaMantia AS (2004) Loss of Gli3 and Shh function disrupts olfactory axon trajectories. J Comp Neurol 472:292-307. CrossRef Medline

Bielle F, Griveau A, Narboux-Nême N, Vigneau S, Sigrist M, Arber S, Wassef M, Pierani A (2005) Multiple origins of Cajal-Retzius cells at the borders of the developing pallium. Nat Neurosci 8:1002-1012. CrossRef Medline

Britz O, Mattar P, Nguyen L, Langevin LM, Zimmer C, Alam S, Guillemot F, Schuurmans C (2006) A role for proneural genes in the maturation of cortical progenitor cells. Cereb Cortex 16 [Suppl 1]:i138-i151. Medline

Cau E, Casarosa S, Guillemot F (2002) Mash1 and Ngn1 control distinct steps of determination and differentiation in the olfactory sensory neuron lineage. Development 129:1871-1880. Medline

Caviness VS Jr (1982) Neocortical histogenesis in normal and reeler mice: a developmental study based upon $[3 \mathrm{H}]$ thymidine autoradiography. Brain Res 256:293-302. Medline

Chou SJ, Perez-Garcia CG, Kroll TT, O’Leary DD (2009) Lhx2 specifies regional fate in Emx1 lineage of telencephalic progenitors generating cerebral cortex. Nat Neurosci 12:1381-1389. CrossRef Medline

Conforti F, Sayan AE, Sreekumar R, Sayan BS (2012) Regulation of p73 activity by post-translational modifications. Cell Death Dis 3:e285. CrossRef Medline

D’Arcangelo G, Miao GG, Curran T (1996) Detection of the reelin breakpoint in reeler mice. Brain Res Mol Brain Res 39:234-236. CrossRef Medline

de Castro F (2009) Wiring olfaction: the cellular and molecular mechanisms that guide the development of synaptic connections from the nose to the cortex. Front Neurosci 3:52. CrossRef Medline

de Carlos JA, López-Mascaraque L, Valverde F (1996) Dynamics of cell migration from the lateral ganglionic eminence in the rat. J Neurosci 16 : 6146-6156. Medline

Dixit R, Lu F, Cantrup R, Gruenig N, Langevin LM, Kurrasch DM, Schuurmans C (2011a) Efficient gene delivery into multiple CNS territories using in utero electroporation. J Vis Exp pii:2957. CrossRef Medline

Dixit R, Zimmer C, Waclaw RR, Mattar P, Shaker T, Kovach C, Logan C, Campbell K, Guillemot F, Schuurmans C (2011b) Ascll participates in Cajal-Retzius cell development in the neocortex. Cereb Cortex 21:25992611. CrossRef Medline

Flames N, Hobert O (2009) Gene regulatory logic of dopamine neuron differentiation. Nature 458:885-889. CrossRef Medline

Fode C, Gradwohl G, Morin X, Dierich A, LeMeur M, Goridis C, Guillemot F (1998) The bHLH protein NEUROGENIN 2 is a determination factor for epibranchial placode-derived sensory neurons. Neuron 20:483-494. CrossRef Medline

Fode C, Ma Q, Casarosa S, Ang SL, Anderson DJ, Guillemot F (2000) A role for neural determination genes in specifying the dorsoventral identity of telencephalic neurons. Genes Dev 14:67-80. Medline

Fujitani M, Cancino GI, Dugani CB, Weaver IC, Gauthier-Fisher A, Paquin A, Mak TW, Wojtowicz MJ, Miller FD, Kaplan DR (2010) TAp73 acts via the bHLH Hey2 to promote long-term maintenance of neural precursors. Curr Biol 20:2058-2065. CrossRef Medline

García-Moreno F, López-Mascaraque L, De Carlos JA (2007) Origins and migratory routes of murine Cajal-Retzius cells. J Comp Neurol 500:419432. CrossRef Medline

Gorski JA, Talley T, Qiu M, Puelles L, Rubenstein JL, Jones KR (2002) Cortical excitatory neurons and glia, but not GABAergic neurons, are produced in the Emx1-expressing lineage. J Neurosci 22:6309-6314. Medline

Griveau A, Borello U, Causeret F, Tissir F, Boggetto N, Karaz S, Pierani A (2010) A novel role for Dbx1-derived Cajal-Retzius cells in early regionalization of the cerebral cortical neuroepithelium. PLoS Biol 8:e1000440. CrossRef Medline
Gunhaga L, Marklund M, Sjödal M, Hsieh JC, Jessell TM, Edlund T (2003) Specification of dorsal telencephalic character by sequential Wnt and FGF signaling. Nat Neurosci 6:701-707. CrossRef Medline

Hanashima C, Fernandes M, Hebert JM, Fishell G (2007) The role of Foxg1 and dorsal midline signaling in the generation of Cajal-Retzius subtypes. J Neurosci 27:11103-11111. CrossRef Medline

Hevner RF, Shi L, Justice N, Hsueh Y, Sheng M, Smiga S, Bulfone A, Goffinet AM, Campagnoni AT, Rubenstein JL (2001) Tbrl regulates differentiation of the preplate and layer 6. Neuron 29:353-366. CrossRef Medline

Hevner RF, Neogi T, Englund C, Daza RA, Fink A (2003) Cajal-Retzius cells in the mouse: transcription factors, neurotransmitters, and birthdays suggest a pallial origin. Brain Res Dev Brain Res 141:39-53. CrossRef Medline

Hirabayashi Y, Itoh Y, Tabata H, Nakajima K, Akiyama T, Masuyama N, Gotoh Y (2004) The Wnt/beta-catenin pathway directs neuronal differentiation of cortical neural precursor cells. Development 131:2791-2801. CrossRef Medline

Hirata T, Nomura T, Takagi Y, Sato Y, Tomioka N, Fujisawa H, Osumi N (2002) Mosaic development of the olfactory cortex with Pax6-dependent and -independent components. Brain Res Dev Brain Res 136:17-26. CrossRef Medline

Hirata T, Kumada T, Kawasaki T, Furukawa T, Aiba A, Conquet F, Saga Y, Fukuda A (2012) Guidepost neurons for the lateral olfactory tract: expression of metabotropic glutamate receptor 1 and innervation by glutamatergic olfactory bulb axons. Dev Neurobiol 72:1559-1576. CrossRef Medline

Howell BW, Hawkes R, Soriano P, Cooper JA (1997) Neuronal position in the developing brain is regulated by mouse disabled-1. Nature 389:733737. CrossRef Medline

Imayoshi I, Shimogori T, Ohtsuka T, Kageyama R (2008) Hes genes and neurogenin regulate nonneural versus neural fate specification in the dorsal telencephalic midline. Development 135:2531-2541. CrossRef Medline

Israsena N, Hu M, Fu W, Kan L, Kessler JA (2004) The presence of FGF2 signaling determines whether beta-catenin exerts effects on proliferation or neuronal differentiation of neural stem cells. Dev Biol 268:220-231. CrossRef Medline

Kohwi M, Osumi N, Rubenstein JL, Alvarez-Buylla A (2005) Pax6 is required for making specific subpopulations of granule and periglomerular neurons in the olfactory bulb. J Neurosci 25:6997-7003. CrossRef Medline

Li S, Mattar P, Zinyk D, Singh K, Chaturvedi CP, Kovach C, Dixit R, Kurrasch DM, Ma YC, Chan JA, Wallace V, Dilworth FJ, Brand M, Schuurmans C (2012) GSK3 temporally regulates neurogenin 2 proneural activity in the neocortex. J Neurosci 32:7791-7805. CrossRef Medline

Long JE, Garel S, Depew MJ, Tobet S, Rubenstein JL (2003) DLX5 regulates development of peripheral and central components of the olfactory system. J Neurosci 23:568-578. Medline

Long JE, Garel S, Alvarez-Dolado M, Yoshikawa K, Osumi N, Alvarez-Buylla A, Rubenstein JL (2007) Dlx-dependent and -independent regulation of olfactory bulb interneuron differentiation. J Neurosci 27:3230-3243. CrossRef Medline

Ma Q, Chen Z, del Barco Barrantes I, de la Pompa JL, Anderson DJ (1998) Neurogenin 1 is essential for the determination of neuronal precursors for proximal cranial sensory ganglia. Neuron 20:469-482. CrossRef Medline

Machon O, Backman M, Krauss S, Kozmik Z (2005) The cellular fate of cortical progenitors is not maintained in neurosphere cultures. Mol Cell Neurosci 30:388-397. CrossRef Medline

Marín-Padilla M (1998) Cajal-Retzius cells and the development of the neocortex. Trends Neurosci 21:64-71. CrossRef Medline

Mattar P, Britz O, Johannes C, Nieto M, Ma L, Rebeyka A, Klenin N, Polleux F, Guillemot F, Schuurmans C (2004) A screen for downstream effectors of Neurogenin2 in the embryonic neocortex. Dev Biol 273:373-389. CrossRef Medline

Mattar P, Langevin LM, Markham K, Klenin N, Shivji S, Zinyk D, Schuurmans C (2008) Basic helix-loop-helix transcription factors cooperate to specify a cortical projection neuron identity. Mol Cell Biol 28:1456-1469. CrossRef Medline

Meyer G, Perez-Garcia CG, Abraham H, Caput D (2002) Expression of p73 and Reelin in the developing human cortex. J Neurosci 22:4973-4986. Medline

Meyer G, Cabrera Socorro A, Perez Garcia CG, Martinez Millan L, Walker N, 
Caput D (2004) Developmental roles of p73 in Cajal-Retzius cells and cortical patterning. J Neurosci 24:9878-9887. CrossRef Medline

Mohamed OA, Clarke HJ, Dufort D (2004) Beta-catenin signaling marks the prospective site of primitive streak formation in the mouse embryo. Dev Dyn 231:416-424. CrossRef Medline

Nikoletopoulou V, Plachta N, Allen ND, Pinto L, Götz M, Barde YA (2007) Neurotrophin receptor-mediated death of misspecified neurons generated from embryonic stem cells lacking Pax6. Cell Stem Cell 1:529-540. CrossRef Medline

O'Dell RS, Ustine CJ, Cameron DA, Lawless SM, Williams RM, Zipfel WR, Olson EC (2012) Layer 6 cortical neurons require Reelin-Dabl signaling for cellular orientation, Golgi deployment, and directed neurite growth into the marginal zone. Neural Dev 7:25. CrossRef Medline

Pearson BJ, Doe CQ (2004) Specification of temporal identity in the developing nervous system. Annu Rev Cell Dev Biol 20:619-647. CrossRef Medline

Puelles L, Kuwana E, Puelles E, Bulfone A, Shimamura K, Keleher J, Smiga S, Rubenstein JL (2000) Pallial and subpallial derivatives in the embryonic chick and mouse telencephalon, traced by the expression of the genes Dlx-2, Emx-1, Nkx-2.1, Pax-6, and Tbr-1. J Comp Neurol 424:409-438. CrossRef Medline

Saha B, Hari P, Huilgol D, Tole S (2007) Dual role for LIM-homeodomain gene Lhx2 in the formation of the lateral olfactory tract. J Neurosci 27: 2290-2297. CrossRef Medline

Saino-Saito S, Cave JW, Akiba Y, Sasaki H, Goto K, Kobayashi K, Berlin R, Baker H (2007) ER81 and CaMKIV identify anatomically and phenotypically defined subsets of mouse olfactory bulb interneurons. J Comp Neurol 502:485-496. CrossRef Medline

Sakamoto M, Hirata H, Ohtsuka T, Bessho Y, Kageyama R (2003) The basic helix-loop-helix genes Hesr1/Heyl and Hesr2/Hey2 regulate maintenance of neural precursor cells in the brain. J Biol Chem 278:4480844815. CrossRef Medline

Sarma AA, Richard MB, Greer CA (2011) Developmental dynamics of piriform cortex. Cereb Cortex 21:1231-1245. CrossRef Medline

Sato Y, Hirata T, Ogawa M, Fujisawa H (1998) Requirement for earlygenerated neurons recognized by monoclonal antibody lot 1 in the formation of lateral olfactory tract. J Neurosci 18:7800-7810. Medline

Schuurmans C, Armant O, Nieto M, Stenman JM, Britz O, Klenin N, Brown C, Langevin LM, Seibt J, Tang H, Cunningham JM, Dyck R, Walsh C, Campbell K, Polleux F, Guillemot F (2004) Sequential phases of cortical specification involve Neurogenin-dependent and -independent pathways. EMBO J 23:2892-2902. CrossRef Medline

Shaker T, Dennis D, Kurrasch DM, Schuurmans C (2012) Neurog1 and Neurog2 coordinately regulate development of the olfactory system. Neural Dev 7:28. CrossRef Medline

Smart IH, Smart M (1977) The location of nuclei of different labelling intensities in autoradiographs of the anterior forebrain of postnatial mice injected with $[3 \mathrm{H}]$ thymidine on the eleventh and twelfth days postconception. J Anat 123:515-525. Medline

Stenman J, Toresson H, Campbell K (2003) Identification of two distinct progenitor populations in the lateral ganglionic eminence: implications for striatal and olfactory bulb neurogenesis. J Neurosci 23:167-174. Medline
Supèr H, Soriano E, Uylings HB (1998) The functions of the preplate in development and evolution of the neocortex and hippocampus. Brain Res Brain Res Rev 27:40-64. CrossRef Medline

Takahashi T, Goto T, Miyama S, Nowakowski RS, Caviness VS Jr (1999) Sequence of neuron origin and neocortical laminar fate: relation to cell cycle of origin in the developing murine cerebral wall. J Neurosci 19: 10357-10371. Medline

Takiguchi-Hayashi K, Sekiguchi M, Ashigaki S, Takamatsu M, Hasegawa H, Suzuki-Migishima R, Yokoyama M, Nakanishi S, Tanabe Y (2004) Generation of reelin-positive marginal zone cells from the caudomedial wall of telencephalic vesicles. J Neurosci 24:2286-2295. CrossRef Medline

Tomioka N, Osumi N, Sato Y, Inoue T, Nakamura S, Fujisawa H, Hirata T (2000) Neocortical origin and tangential migration of guidepost neurons in the lateral olfactory tract. J Neurosci 20:5802-5812. Medline

Vergaño-Vera E, Yusta-Boyo MJ, de Castro F, Bernad A, de Pablo F, VicarioAbejón C (2006) Generation of GABAergic and dopaminergic interneurons from endogenous embryonic olfactory bulb precursor cells. Development 133:4367-4379. CrossRef Medline

Vyas A, Saha B, Lai E, Tole S (2003) Paleocortex is specified in mice in which dorsal telencephalic patterning is severely disrupted. J Comp Neurol 466: 545-553. CrossRef Medline

Wang Z, Shu W, Lu MM, Morrisey EE (2005) Wnt7b activates canonical signaling in epithelial and vascular smooth muscle cells through interactions with Fzd1, Fzd10, and LRP5. Mol Cell Biol 25:5022-5030. CrossRef Medline

Watanabe K, Kamiya D, Nishiyama A, Katayama T, Nozaki S, Kawasaki H, Watanabe Y, Mizuseki K, Sasai Y (2005) Directed differentiation of telencephalic precursors from embryonic stem cells. Nat Neurosci 8:288296. CrossRef Medline

Winpenny E, Lebel-Potter M, Fernandez ME, Brill MS, Götz M, Guillemot F, Raineteau O (2011) Sequential generation of olfactory bulb glutamatergic neurons by Neurog2-expressing precursor cells. Neural Dev 6:12. CrossRef Medline

Wood JG, Martin S, Price DJ (1992) Evidence that the earliest generated cells of the murine cerebral cortex form a transient population in the subplate and marginal zone. Brain Res Dev Brain Res 66:137-140. CrossRef Medline

Yoshida M, Assimacopoulos S, Jones KR, Grove EA (2006) Massive loss of Cajal-Retzius cells does not disrupt neocortical layer order. Development 133:537-545. CrossRef Medline

Yun K, Potter S, Rubenstein JL (2001) Gsh2 and Pax6 play complementary roles in dorsoventral patterning of the mammalian telencephalon. Development 128:193-205. Medline

Yun K, Garel S, Fischman S, Rubenstein JL (2003) Patterning of the lateral ganglionic eminence by the Gsh1 and Gsh2 homeobox genes regulates striatal and olfactory bulb histogenesis and the growth of axons through the basal ganglia. J Comp Neurol 461:151-165. CrossRef Medline

Zhao C, Guan W, Pleasure SJ (2006) A transgenic marker mouse line labels Cajal-Retzius cells from the cortical hem and thalamocortical axons. Brain Res 1077:48-53. CrossRef Medline

Zimmer C, Lee J, Griveau A, Arber S, Pierani A, Garel S, Guillemot F (2010) Role of Fgf8 signalling in the specification of rostral Cajal-Retzius cells. Development 137:293-302. CrossRef Medline 